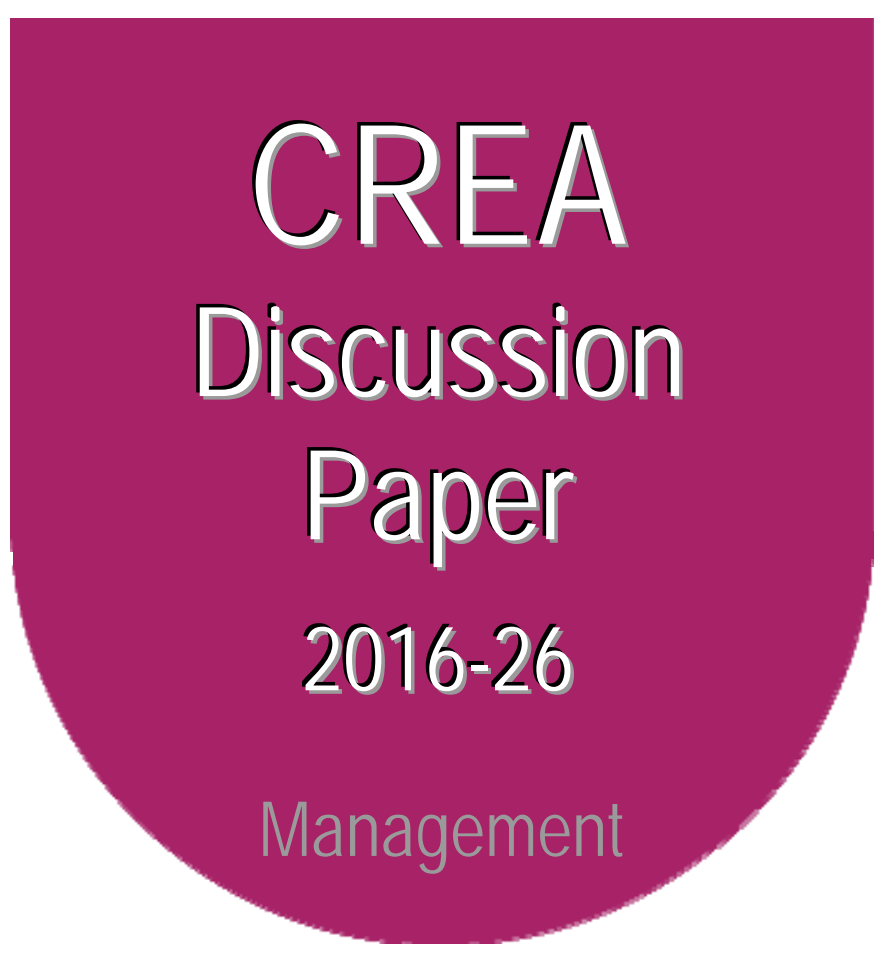

Centre for Research in Economics and Management University of Luxembourg

\title{
Innovation, Creative Destruction and Structural Change: Firm-level Evidence from European Countries
}

available online : http://wwwfr.uni.lu/recherche/fdef/crea/publications2/discussion_papers

Bernhard Dachs, Austrian Institute of Technology, Vienna Martin Hud, ZEW Centre for European Economic Research, Mannheim Christian Köhler, ZEW Centre for European Economic Research, Mannheim Bettina Peters, ZEW, Mannheim, and CREA, University of Luxembourg

November, 2016

For editorial correspondence, please contact: crea@uni.lu

University of Luxembourg Faculty of Law, Economics and Finance 162A, avenue de la Faïencerie L-1511 Luxembourg 


\title{
Innovation, Creative Destruction and Structural Change: Firm-level Evidence from European Countries*
}

\author{
Bernhard Dachs ${ }^{\dagger}$, Martin Hud $\%$ \\ Christian Köhler $\mathcal{\&}$ and Bettina Peters ${ }^{\star}$
}

November 2016

\begin{abstract}
The shift of employment from lower to higher productive firms is an important driver for structural change and industry dynamics. We investigate this reallocation in terms of employment gains and losses from innovation. New employment created by product innovation may be offset by employment losses in related products, known as 'cannibalisation' or 'business stealing' effects in the literature, by employment losses from process and organisational innovation and by general productivity increases. The paper investigates this effect empirically with a large dataset from the European Community Innovation Survey (CIS). We find that employment gains and losses increase with technology intensity of the sector. High-technology manufacturing shows the strongest employment gains and losses from innovation, followed by knowledge-intensive services, low-technology manufacturing and less knowledge-intensive services. The net contribution of innovation to employment growth is mostly positive, an exception being manufacturing industries in recession periods.
\end{abstract}

Keywords: Innovation, employment, reallocation, technology intensity, compensation effect, displacement effect, cannibalisation effect.

JEL classification: O33, J23, C26, D2

* We would like to thank the two anonymous reviewers for their valuable comments and suggestions. We furthermore thank Geneviève Villette at Eurostat, Luxembourg, for supporting us with the CIS data. Part of this research is based on a project done for the European Commission under the Framework Contract ENTR/2009/033. The opinions expressed in this study are those of the authors and do not represent the European Commission's official position. The usual disclaimer applies.

${ }^{\dagger}$ Bernhard Dachs: AIT Austrian Institute of Technology, Tech Gate Vienna, Donau-City-Strasse 1, 1220 Vienna, Austria. E-mail: Bernhard.Dachs@ait.ac.at.

${ }^{7}$ Martin Hud: ZEW Centre for European Economic Research, L7,1, 68161 Mannheim, Germany. E-mail: hud@zew.de

${ }^{\S}$ Christian Köhler: ZEW Centre for European Economic Research, L7,1, 68161 Mannheim, Germany. Email: christian.koehler@rocketmail.com.

' Bettina Peters, ZEW Centre for European Economic Research, L7,1, 68161 Mannheim, Germany and CREA, University of Luxembourg, 162a, avenue de la Faiencerie, L-1511, Luxembourg. E-mail: b.peters@zew.de. 


\section{Introduction}

The reallocation of employment and capital between firms is a major determinant of structural change and aggregate productivity growth, together with firm entries and exits (Caves 1998; Bartelsman and Doms 2000; Krüger 2008; Dosi and Nelson 2010). This reallocation is largely driven by innovation and the use of new technologies. A famous illustration of long-term structural change as a result of major product, process and organisational innovations is Joseph Schumpeter's (1942) notion of 'creative destruction'.

The paper aims at studying these reallocation dynamics. In particular, we ask in which sectors job gains and losses from innovation are highest, and to what degree and in which situations firms can compensate the job-destroying effects of innovation with job creation, leading to a positive overall employment effect. Our analysis utilises firm-level data but focuses on differences in employment dynamics at the sectoral and industry level. We distinguish four sector groups (high-tech manufacturing, low-tech manufacturing, knowledge-intensive services and less knowledge-intensive services) and investigate a more disaggregated level by analysing 16 industries. The sectoral and industry level is appropriate for this question because characteristics such as the level of technological opportunity, cumulativeness of the knowledge base or appropriability conditions vary considerably between sectors and industries. These variations in turn determine the innovation behaviour at the firm level (Marsili 2001; Cohen 2010; Dosi and Nelson 2010). Heterogeneity in innovation determinants may also be an important source of heterogeneity in innovation-induced employment creation between industries and sectors.

We employ the model proposed by Harrison et al. (2014) that relates employment changes to product and process innovation at the firm level. Our study extends the work by Harrison et al. (2014) and contributes to the literature in four important dimensions. First, in addition to product and process innovation we account for organisational innovation as a third important type of innovation. Second, we construct a new pooled cross-sectional dataset that merges five waves from the European Community Innovation Survey (CIS) for the period 1998-2010 whereas Harrison et al. (2014) estimate the model using data only for one cross section covering the years 1998-2000. The data contains more than 360,000 firm-level observations of the manufacturing and service sector from 26 European countries. Third, Harrison et al. (2014) only distinguish between manufacturing and services. We study job gains and losses from innovation at the sector and industry level using two different ways of classifying industries according to their technology intensity. This allows us to analyse the interaction between the technology intensity and the effects of innovation on employment. And finally, the long time period of 12 years also allows us to investigate to what extent sectoral displacement and compensation effects of innovation vary over the business cycle. Dachs et al. (2016) showed that aggregate demand conditions influence firm-level innovation outcomes and reallocation dynamics in manufacturing firms. 
The paper is structured as follows: Section 2 presents the relevant literature and develops hypotheses. Section 3 describes the data, while Section 4 and Section 5 discuss the econometric model and the estimation strategy of the paper. Section 6 follows with a discussion of the regression results. Section 7 and Section 8 discuss the results from a decomposition analysis at the sectoral and industry level, respectively. Finally, Section 9 draws conclusions from the study.

\section{Literature Background and Hypotheses}

There is a well-developed research on innovation and employment (for surveys see Chennells and Van Reenen 2002; Vivarelli 2014) that has identified a range of employment-creating as well as employmentdestroying effects of new products, processes or organisation types.

Most importantly, innovation in the form of new products creates additional sales for the firm and therefore increases employment (compensation effect of product innovation; see the surveys cited above). But in general, not all sales generated by new products can be characterised as pure market expansion effects (due to new customers or other non-substitution based sales). New products with a higher utility for consumers and/or a lower price may displace existing products offered by the innovating firm or by its competitors, so that the demand for a new product may come at the expense of demand for existing 'old' products. Hence, product innovation may incur negative externalities to the innovator itself (the 'cannibalisation' effect) or to competitors (the 'business stealing' effect), which may reduce the initial employment-creating effect of product innovation. A well-known example for these adverse effects is from the mobile phone industry. When one of the major brands introduces a new mobile phone, sales of the predecessor but also of rival products usually decrease considerably.

Cannibalisation and business stealing effects found wide recognition in the marketing literature (Chandy and Tellis 1998; Hauser, Tellis and Griffin 2006), but they are also discussed by the literature on R\&D spillovers, the industrial economics literature on market entry or in endogenous models of technological change (Aghion and Howitt 1992). This literature shows that cannibalisation and business stealing effects are frequent: Lomax et al. (1997) find that some cannibalisation is almost inevitable for firms that launch new products, in particular for multi-product firms (Heerde, Srinivasan and Dekimpe 2010). Harrison et al. (2014) estimate that the reallocation due to business stealing can be up to $30 \%$ of the net employment effects created by new products. Exceptions may exist when a new product complements an existing product, or when a new product extends the product range of a firm into new fields, but benefits from the established brand (Lomax et al. 1997). It may also happen that new products incorporating new technologies do not crowd out existing ones, but that the threat of being substituted accelerate innovation in the old technology and as a result also stimulate demand and employment (Howells 2002, Mendonca 2013). However, both Howells (2002) and Mendonca (2013) are rather sceptical if this so called sailing 
ship effect is more than a product of "hindsight assumption and superficial case knowledge" (Howells 2002, p. 902).

Another channel how innovation can influence employment is the labour-saving displacement effect of process innovation (Hall, Lotti and Mairesse 2008; Harrison et al. 2014). Process innovation may reduce labour demand when the same output can be produced with less input. Displacement effects may also occur with organisational innovation or with product innovation when the new product can be produced with less input than the old product. Displacement effects and negative externalities are closely linked; if process (product) innovation allows the firm to produce the existing (new) product at a lower price than before, this cost difference may lead to a lower output price. This stimulates product demand on the one hand but also promotes cannibalisation and business stealing on the other hand. If the product offered becomes substantially cheaper, process innovation may also lead to overall market expansion. The magnitude of this effect is determined by the size of the price reduction, the elasticity of demand and the reactions of competitors to the price reduction. Empirical evidence for this price effect is provided by König, Licht and Buscher (1995), Greenan and Guellec (2000), Smolny (2002) or Lachenmaier and Rottmann (2011) who all find significantly positive overall employment effects of process innovations.

Empirical evidence suggests that the combined effect of positive compensation effects and negative externalities due to cannibalisation and displacement effects is positive, resulting in employment growth at the firm level (Hall, Lotti and Mairesse 2008; Lachenmaier and Rottmann 2011; Harrison et al. 2014) and also at the industry level when taking additional negative externalities due to business stealing into account (Bogliacino and Pianta 2010). Moreover, negative externalities from business stealing are considerably smaller than the positive spillovers from R\&D activity, leading to positive gross social returns to R\&D (Bloom, Schankerman and Van Reenen 2013). Most of these studies investigate employment effects of innovation in the short or medium run and little is known about compensation and displacement effects of innovation in the long run.

There are, however, a number of factors at the level of individual industries and firms that presumably lead to a considerable degree of heterogeneity in the effects of innovation below the aggregate level. Industries differ in a number of technology-related factors including the richness of technological opportunities, the cumulativeness of the knowledge base, or the means to protect and appropriate the economic benefits from innovation (Marsili 2001; Cohen 2010; Dosi and Nelson 2010). We can observe the results of these factors in persistent differences in the prevailing technological trajectories between sectors and distinct technological regimes that shape the directions of technological search in industries (Breschi, Malerba and Orsenigo 2000; Marsili 2001; Castellacci 2007).

In addition to technology-related factors, the strength of compensation and displacement effects as well as of negative externalities of product and process innovation also depends on a number of non-technology factors. User requirements and other demand side characteristics have a crucial role in determining the 
success or failure of innovations. Demand can also influence the intensity and direction of technological search by firms when differences in demand expectations between sectors translate into different incentives to invest in R\&D and innovation (Schmookler 1966; Acemoglu 2002). In addition, the elasticity of demand, the competitive pressure in an industry or the reaction time of competitors are other important determinants of the strength and duration of compensation and displacement effects though little is known in the literature about the duration of these effects.

Technology-related and non-technology factors shape the aforementioned compensation and displacement effects of innovation in a co-evolutionary way. For the sake of simplicity, our basic hypothesis is that firms in an industry characterised by large technological opportunities and fast, disruptive technological change may experience stronger compensation, but also stronger displacement effects from product and process innovation than firms in industries with slow technological change. This is because the high pace of technological change in some industries allows firms to develop and introduce products more frequently, with more new features and a quickly decreasing price/performance ratio. Moreover, industries that have a higher technology intensity also include a higher share of firms with radical innovations which are related with stronger cannibalisation effects (Chandy and Tellis 1998; Heerde, Srinivasan and Dekimpe 2010). We therefore derive the following hypothesis:

\section{H1: Compensation and displacement effects increase with technology intensity of the sector and industry.}

The analysis of this paper also covers service industries, which allows us to analyse additional heterogeneity. Macroeconomic data on average reveal a higher employment growth in services than in manufacturing across European countries (Veugelers 2013). This has been explained by a higher income elasticity of service products compared to manufacturing products and a higher degree of tradability of manufacturing products allowing a stronger shift of manufacturing towards lower-cost countries (Baumol 2012; Veugelers 2013).

There is a long discussion how innovation in service firms differs from innovation in manufacturing firms, and if service and manufacturing innovation can be measured by the same metrics (Tether 2005; Gallouj and Savona 2009). From this literature we know that innovation in services is more often nontechnological, is based to a lesser degree on the application of scientific and formal knowledge, includes more interaction with clients, requires more of the necessary social skills for interaction, and can be protected less efficiently with formal intellectual property rights than innovation in manufacturing. Moreover, service products are more often the result of user-producer interaction and customisation than standardised manufacturing products (Tether, Hipp and Miles 2001; Miles 2005).

If we consider customised products resulting from user-producer innovation as variants of the old standard product and accept a slower pace of technological change in service sectors, we may assume that old products - relative to new products - contribute more to overall employment growth in services than in 
manufacturing. This would imply that less negative externalities, but also less employment creation from innovation:

H2: Compensation and displacement effects are smaller in services than in manufacturing.

\section{Sample and Data Description}

In order to investigate reallocation effects of employment due to innovation and to test our two hypotheses, we make use of the European-wide harmonised Community Innovation Surveys (CIS). CIS is a firm-level survey that is based on the Oslo Manual (latest edition: OECD and Eurostat 2005). The paper employs five waves of CIS data covering the years 1998-2000 (CIS3), 2002-2004 (CIS4), 2004-2006 (CIS2006), 2006-2008 (CIS2008) and 2008-2010 (CIS2010). The merged dataset comprises information from 26 European countries ${ }^{1}$ of which 12 are present in each wave. The non-anonymised micro data were accessed at Eurostat's safecenter. In total, the merged CIS dataset contains 414,474 observations for the five periods. However, due to missing values, in particular for organisational innovation in CIS2006 ${ }^{2}$, we end up with a sample of 361,865 observations. 56\% of all observations are manufacturing firms whereas the other $44 \%$ are service firms (see Table 1 below).

CIS is a representative survey for manufacturing sector and for selected service industries. To further disaggregate the data, we employ two different sectoral classifications. First, we define 19 industries based on NACE ${ }^{3}$ 2-digit industries. Table 7 in the Annex provides the definition of the industries and their sample distribution. Manufacturing of basic and fabricated metals, food and beverages as well as the textile industry are the largest sectors within manufacturing, each accounting for about $14 \%$ of the sample. The largest service sector is wholesale, with a share of 34\%. Subsequently, transport, technical services and telecommunication/information technology have shares ranging from approximately $21 \%$ to $10 \%$ of all service firms. Second, we split sectors according to their technology intensity into four broad sectors. Following Eurostat (2016a,b), we define high-technology manufacturing (HIGH), lowtechnology manufacturing (LOW), knowledge-intensive services (KIS) and less knowledge-intensive services (LKIS). Table 8 in the Annex presents details of this aggregation.

\footnotetext{
Belgium, Bulgaria, Cyprus, Czech Republic, Germany, Denmark, Estonia, Spain, Finland, France, Greece, Croatia, Hungary, Iceland, Italy, Lithuania, Luxembourg, Latvia, Malta, Netherlands, Norway, Portugal, Romania, Sweden, Slovenia and Slovakia.

2 The question on organisational innovation was not mandatory in CIS2006 and it was only asked by 4 out of the 15 countries available at Eurostat. Dachs et al. (2016) checked carefully the robustness of results including and excluding organisational innovation for the aggregate sample.

3 Note that CIS3, CIS4 and CIS2006 use the NACE Rev. 1.1 classification while CIS2008 and CIS2010 employ NACE Rev. 2. A concordance has been used to have a unified classification for the whole period and to define 11 and 8 industries in manufacturing and services, respectively.
} 


\begin{tabular}{|c|c|c|c|c|c|c|c|c|}
\hline \multirow[t]{2}{*}{ CIS } & \multirow[t]{2}{*}{ Period } & \multicolumn{3}{|c|}{ Total } & \multicolumn{2}{|c|}{ Manufacturing } & \multicolumn{2}{|c|}{ Services } \\
\hline & & $\mathbf{N}$ & $\%$ & Cum & $\mathbf{N}$ & $\%$ & $\mathbf{N}$ & $\%$ \\
\hline CIS 3 & $1998-2000$ & 65,729 & 18.16 & 18.16 & 42,378 & 20.76 & 23,351 & 14.80 \\
\hline CIS 4 & 2002-2004 & 76,395 & 21.11 & 39.28 & 43,450 & 21.29 & 32,945 & 20.88 \\
\hline CIS2006 & 2004-2006 & 23,253 & 6.43 & 45.70 & 13,116 & 6.43 & 10,137 & 6.43 \\
\hline CIS2008 & 2006-2008 & 94,480 & 26.11 & 71.81 & 52,029 & 25.49 & 42,451 & 26.91 \\
\hline CIS2010 & 2008-2010 & 102,008 & 28.19 & 100.00 & 53,140 & 26.03 & 48,868 & 30.98 \\
\hline Pooled & 1998-2010 & 361,865 & 100 & & 204,113 & 100.0 & 157,752 & 100.0 \\
\hline
\end{tabular}

Source: CIS3, CIS4, CIS2006, CIS2008 and CIS2010, Eurostat; own calculation.

Furthermore, in order to investigate whether reallocation effects of innovation are robust to different phases of the business cycle, we follow Lucchese and Pianta (2012) and Dachs et al. (2016) and additionally split the sample into four business cycle periods: upturn, boom, downturn and recession. The business cycle phases are defined based on the country-specific two-year GDP growth rates using GDP data published by Eurostat. The GDP growth is defined over a two-year period because each CIS wave covers a three-year reference period. An upturn is defined as a period with positive and increasing GDP growth. A boom is the last period of positive and increasing GDP growth before a downturn starts. In downturns GDP growth is positive but decreasing, whereas a recession is characterised by negative GDP growth.

In addition to a broad range of innovation indicators, the CIS contains general firm information as well. The central non-innovation variables for the analysis are employment and sales growth at the firm level. Each CIS wave contains information about employment and sales in a given year $\mathrm{t}$ and in year $\mathrm{t}-2$, thus allowing us to calculate employment and sales growth at the firm level.

The CIS measures employment by the average total number (headcount) of employees of a firm in a certain year. ${ }^{4}$ Unfortunately, the CIS does not provide any information on hours worked or on the total wage bill which we would have preferred. We calculate employment growth as the percent change of the headcount employment of the firm from year t-2 to year $t(E M P)$. As we consider employment growth and innovation for the same period, the paper estimates the employment effects of innovation within a (maximum of) three-year period. Presumably, this is not enough to assess the entire employment effects. While it is likely that displacement effects of innovations are realised closer to the time of their introduction, positive compensation effects of product innovations may stimulate demand and

\footnotetext{
4 The core CIS questionnaire does not further specify the term employment. Even though not explicitly stated in the questionnaire, the term total employees in headcounts implies that part-time workers should be included. On the contrary, agency workers should not be counted because they are employees of the temporary employment agencies. Total employment of course also includes R\&D personnel. Countries are also allowed using administrative data for employment instead of asking firms within the CIS.
} 
employment also in the long-run. Compensation effects of process and organisational innovations may also only appear with a certain delay after the firm has realised cost reductions and decided to pass them on to consumers. Estimating long-run effects would require a panel data analysis that is not feasible with the data at hand. ${ }^{5}$ Hence, our results should be interpreted as lower bounds of innovation-induced employment effects.

Figure 1 depicts employment growth over the business cycle for high-tech and low-tech manufacturing, knowledge-intensive services and less knowledge-intensive services. Employment growth is calculated as the weighted average two-year employment growth rates across all firms in a given sector group. Hence, it cannot be directly compared with growth rates based on official employment statistics which are calculated by taking the ratio of the sum of changes in employment for all firms to the sum of employed personnel. Due to the different calculation method, average employment growth rates are stronger affected by very fast growing firms. ${ }^{6}$ Another source of deviation stems from that CIS data cannot account for employment losses from firm closures, because these firms do not enter the data. The same holds for employment in very small firms with less than 10 employees, which includes a number of startups.

In both groups of manufacturing firms, the same pro-cyclical movement of average employment growth appears. Both groups exhibit a clear negative employment growth in the recession phases, whereas the highest growth can be observed in the boom and upturn phases of the business cycle. The knowledgeintensive service sector also shows a pro-cyclical employment growth, but has much higher growth rates than manufacturing and no decrease during recession periods which is consistent with LFS figures. An exemption from a strictly pro-cyclical development of employment growth rates can be found in less knowledge-intensive services where the growth rates have been highest during the upturns.

For all business cycle periods employment gains are larger in knowledge-intensive services than in less knowledge-intensive services. This could be a first indication of hypothesis H1. Likewise, average employment growth in high-tech manufacturing firms exceeds that in low-tech manufacturing firms during boom and downturn periods. Employment losses during recessions, in contrast, are smaller in high-tech than in low-tech manufacturing, which would contradict H1. Total employment gains and

\footnotetext{
See the more detailed explanation at the end of this section.

6 While the average employment growth is $10.3 \%$ in KIS and 7.6\% in LKIS in our sample, the median employment growth is much lower with $4.5 \%$ and $0.0 \%$. The same pattern is found for both manufacturing groups (HIGH: $3.8 \%$ and $0.0 \%$; LOW: $3.0 \%$ and $0.0 \%$ ). Due to the different calculation method, it might even be that we simultaneously observe an overall contraction of employment in a certain sector and a positive average employment growth at the firm level in this sector if employment e.g. strongly decreases (increases) in larger (smaller) firms. For comparison, we therefore calculated the average two-year employment growth rate for the period 2000-2010 based on the EU Labour Force Survey (LFS) statistics (here average means over the period 2000-2010). Employment growth based on LFS statistics is similarly high for KIS (8.7\%), but substantially lower for LKIS (1.3 \%). As for CIS data, LFS statistics show lower employment growth for both manufacturing groups (HIGH: -2.9\%; LOW: $-1.4 \%$ ).
} 
losses in Figure 1, however, are the sum of compensation and displacement effects which have to be split up into its single effects.

\section{Figure 1: Employment growth by sector groups and business cycle, 1998-2010}

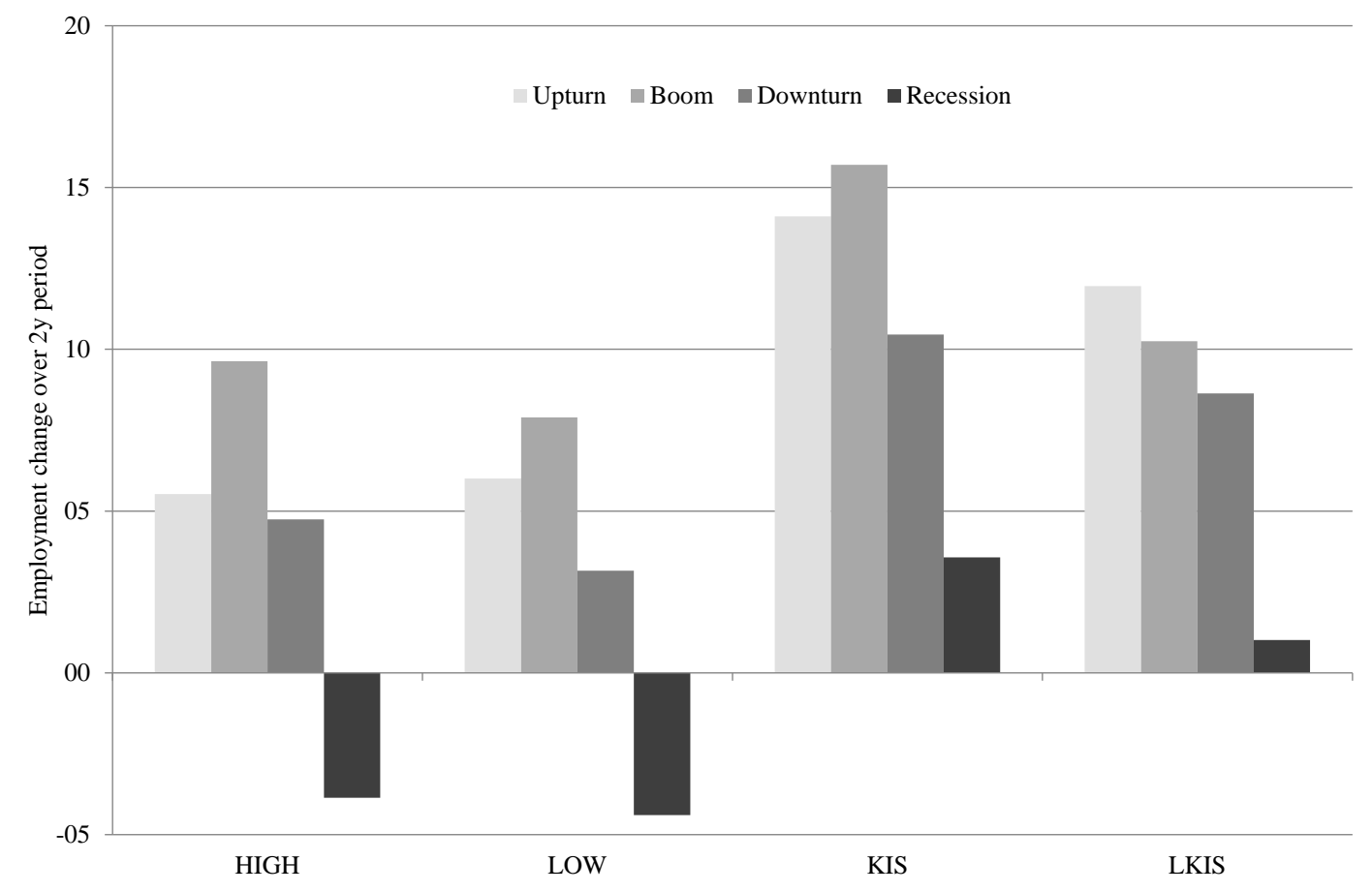

Notes: Depicted are weighted average two-year employment growth rates across all firms in a given sector and business cycle phase. Weighting factors are sample weights that extrapolate to the population number of firms in each stratum. Sample weights are based on the (non-response corrected) inverse drawing probabilities in each stratum and are provided by Eurostat.

Source: CIS3, CIS4, CIS2006, CIS2008 and CIS2010, Eurostat; own calculation.

The main independent variables used in the empirical analysis are different measures of innovation from the CIS, which are based on the Oslo Manual (OECD and Eurostat 2005). Product innovation is captured in the CIS by the question if the firm has introduced any new or considerably improved product to the market during the last three years (t, t-1 and t-2), regardless of whether the product was new to the market or just new to the firm. The product (good or service) should be new or significantly improved with respect to its capabilities, user friendliness, components or sub-systems. Another key variable that we will exploit in the econometric analysis is the share of sales in year $t$ with product innovations introduced in $t$, $\mathrm{t}-1$ and $\mathrm{t}-2$. We use this information to generate the sales growth rate between $\mathrm{t}$ and $\mathrm{t}-2$ that stems from new products $\left(S G R \_N E W P D\right)^{7}$. The sales growth due to new products is used in the econometric model as a quantitative indicator for the level of product innovation in the firm.

Process innovation (PC), in contrast, is measured by a dummy variable that takes on the value one if the firm has introduced at least one new or significantly improved production process, distribution method, or

\footnotetext{
The sales growth rate between $t$ and $t-2$ that stems from new products (SGR_NEWPD) is calculated as share of sales in year $t$ with new products which have been introduced between $\mathrm{t}$ and $\mathrm{t}-2$ times the ratio of year $\mathrm{t}$ 's sales divided by the sales of $\mathrm{t}-2$.
} 
supporting activity for internal processes. We measure organisational innovation (ORGA) by a dummy variable that takes on the value one if the firm has implemented at least one of the following types of organisational innovations: (i) new business practices for organising procedures (e.g. supply chain management, business re-engineering, lean production), (ii) new methods of organising work responsibilities and decision making (e.g. team work, decentralisation, delayering) and (iii) new methods of organising external relations with other firms or public institutions (e.g. partnerships, alliances, in- and outsourcing). Both, the process and the organisational innovation variables take on the value zero if there is no such innovation. The next section describes the econometric model that we use in order to identify compensation and displacement effects of these three types of innovation.

\section{Econometric Model, Empirical Implementation, Identification and Estimation}

In order to investigate employment effects of innovation, we adopt the multi-product approach developed by Harrison et al. (2008, 2014). The original model establishes a relationship between employment growth and sales growth due to new products and, process innovation. As already mentioned our analysis will extend the study and results by Harrison et al. in four important dimensions: (i) we additionally account for organisational innovation; (ii) we focus on compensation and displacement effects of innovation at the sectoral and industry level; (iii) we make use of a pooled cross-sectional dataset covering the period 1998-2010 that (iv) allows us to study whether sectoral employment effects of innovation varies over the business cycle or not. We shortly describe the main features of the model below. For a more detailed description we refer to Harrison et al. (2014).

\subsection{Econometric Model}

Consider a firm that produces a set of products in a specific point of time $t=1$. These products are labelled old (existing) products. Between $\mathrm{t}=1$ and $\mathrm{t}=2$, a second point of time, the firm can decide to introduce a new set of products. Due to the definition of innovation in CIS data, this reference period between $\mathrm{t}=1$ and $\mathrm{t}=2$ covers a three-year period in the empirical analysis. The model is fully flexible whether the new product substitutes the old product (which captures the cannibalisation effect) or whether it enhances the demand of the old product in case of complementarity. Firm $i$ 's output of the old product at time $\mathrm{t}=1,2, \quad Y_{1 t i}$, is produced according to the production functions $Y_{11 i}=\theta_{11 i} * F\left(L_{11 i}, X_{11 i}\right) e^{\eta_{i}}$ and $Y_{12 i}=\theta_{12 i} * F\left(L_{12 i}, X_{12 i}\right) e^{\eta_{i}-u_{i}}$, where $\theta_{1 t}$ is an efficiency parameter in the production of the old product at time t, $L_{1 t}$ measures the labour input and $X_{1 t}$ summarises other variable inputs like capital and material. $\eta_{i}$ captures time-constant firm-specific unobserved productivity shocks whereas $u_{i}$ accounts for unanticipated productivity shocks. Furthermore, output of 
the new product at time $\mathrm{t}=2, Y_{22 i}$, is generated by $Y_{22 i}=\theta_{22 i} * F\left(L_{22 i}, X_{22 i}\right) e^{\eta_{i}-v_{i}}$, where $\theta_{22}, L_{22}, X_{22}$ and $\eta_{i}$ are defined accordingly for the new product and $v_{i}$ accounts for unanticipated productivity shocks in the production of the new product. Harrison et al. (2014) show that under these fairly general assumptions employment growth $l$, defined as $\left(L_{12}+L_{22}-L_{11}\right) / L_{11}$, can be written as: $l=\alpha+y_{1}+\beta y_{2}+u$. Employment growth $l$ originates from the growth of real output of old products, $y_{1}$, and the growth in real output that is due to new products, $y_{2}{ }^{8}$ Furthermore, it stems from efficiency changes in the production of old products, $\alpha$, which we assume are the sum of efficiency gains due to process innovation $\left(\alpha_{1} \cdot p c\right)$, organisational innovation $\left(\alpha_{2} \cdot\right.$ orga $)$ and efficiency improvements unrelated to the firm's own innovation activities, e.g. as a result of learning effects, spillovers, inputs of higher quality, selling or shutting down of unprofitable business units or mergers and acquisitions. This leads to the following relationship between employment growth $l$ and the independent variables:

$$
l=\alpha_{0}+\alpha_{1} p c+\alpha_{2} \text { orga }+y_{1}+\beta y_{2}+u
$$

Note that firm-fixed effects have been cancelled out in the growth formulation.

In the model $\beta$ measures the relative efficiency of new products relative to existing products $\left(\theta_{11} / \theta_{22}\right)$ and $\beta y_{2}$ measures the average compensation effect (direct demand effect) of product innovation. Ceteris paribus, new products will generate less employment growth if their production is more efficient than the production technology of the old products. In contrast, $\alpha_{1}$ and $\alpha_{2}$ measure the mean displacement effects of process and organisational innovations. Note that the change in the output production of old products $y_{1}$ may be provoked by autonomous demand changes due to changes in consumer preferences but more importantly also by the firm's own new product, the induced change being negative for substitutes (cannibalisation effect) and positive for complements. But it also accounts for demand shifts for old products due to new products introduced by rivals (business stealing) and price reductions following own process innovations (compensation effects of process innovation). Unfortunately, only the existence of additional demand data would allow us to disentangle the different externality effects (cannibalisation and business stealing of product innovation and compensation effect of process innovation) captured by $y_{1}$. In the model, the coefficient of the real output growth, $y_{1}$, is equal to one and can thus be subtracted from $l$.

8 Note: Since new products have not been produced in $\mathrm{t}=1$, we cannot measure the real output growth of new products. Instead, $y_{2}$ is defined as $y_{2}=\bar{Y}_{22} / Y_{11}=\left(Y_{22} e^{v}\right) / Y_{11}$ which is the output of the new product (excluding unanticipated productivity shocks) at $\mathrm{t}=2$ to the output of the old product at $\mathrm{t}=1$ and therefore captures the real output growth rate due to new products. 


\subsection{Empirical Implementation}

Unfortunately, we cannot directly estimate equation (1) since we cannot observe real output growth rates in our data. Instead, we replace the unobserved growth rates by the observable nominal output growth rates measured as sales growth. This yields the following estimation equation (2):

$$
l-\left(g_{1}-\tilde{\pi}_{1}\right)=\alpha_{0}+\alpha_{1} p c+\alpha_{2} \text { orga }+\beta g_{2}+\varepsilon
$$

In our data $l$ is measured by the variable $E M P$, i.e. the employment growth rate (in headcounts) between $\mathrm{t}$ and $\mathrm{t}-2$. $p c$ is measured by the variable $P C$, a binary indicator that equals one if the firms has introduced at least one process innovation but no product innovation. This stricter definition of $P C$ allows us to unambiguously identify the displacement effects associated with the introduction of process innovations in the production of old products and not to mix it up with process innovations necessary to introduce new products. orga is measured by the dummy variable ORGA that equals one if the firm has introduced at least one organisational innovation. The nominal sales growth of the old products, $g_{1}$, and the sales growth due to the new products, $g_{2}$, are defined as $g_{1}=y_{1}+\pi_{1}$ and $g_{2}=\left(1+\pi_{2}\right) y_{2}$. Both variables can be calculated from CIS data. $g_{2}$ is measured by the variable $S G R \_N E W P D$ which we derived as the share of sales due to new products in $t$ times the ratio of sales in $\mathrm{t}$ and $\mathrm{t}-2 . g_{1}$ is calculated as the total sales growth rate (the change of turnover between $\mathrm{t}$ and $t-2$ ), $g$, minus $g_{2}$.

$\pi_{1}$ measures the unobserved price growth rate of old products at the firm level. We proxy $\pi_{1}$ by the price growth rate of old products at the country-industry (2-digit) level, $\tilde{\pi}_{1}$ (using producer price indices published by Eurostat). Subtracting the proxy for the real output growth of old products, $\left(g_{1}-\tilde{\pi}_{1}\right)$, from employment growth, $l$, allows us to unambiguously estimate the gross effect of process, organisational and product innovations.

\subsection{Identification and Estimation Strategy}

$\pi_{2}$ is defined as the price difference between new products at $t$ and old products at $t-2$ in relation to the price of the old products at $t-2$ at the firm level. The problem is that this price information cannot be observed, not even at a sector level. However, substituting a real rate of change by a nominal rate of change requires price growth information to adequately estimate the effect. As a result, the estimation of $\beta$ suffers from an endogeneity problem caused by measurement errors. This can be seen from the fact that $g_{2}=\left(1+\pi_{2}\right) y_{2}$ is by definition correlated with the new composite error term $\varepsilon=-E\left(\pi_{1}-\tilde{\pi}_{1}\right)-\beta \pi_{2} y_{2}+u . \quad \beta$ as well as the $\alpha$ 's would also be biased if the innovation variables pc, orga and $g_{2}$ were correlated with the unobserved productivity shock $u$ at $\mathrm{t}=2$. However, this is 
rather unlikely to be the case as the innovation decision has most likely be taken before $t=2$ when $u$ is unknown to the firm (see Harrison et al. 2014).

To solve the endogeneity problem of the relative productivity effect $\beta$ caused by measurement error, we employ an instrumental variable (IV) approach to estimate equation (2). The instrument should be correlated with the product innovation success (sales growth rate due to new products) but uncorrelated to relative price differences between new and old new products. We follow Harrison et al. (2014) and use as first instrument RANGE, a binary indicator that measures whether the product innovations were aimed at increasing the product range or not. The idea is that a broadening of the product range addresses new customer bases and generates higher new product sales. Enlarging the range of products, however, does not imply any particular direction of the changes in the price of the new relative to the old product as they can be sold at higher or lower prices than existing products. As two other potential instruments, we employ binary indicators taking on the value one if the firm continuously conducts $R \& D$ activities $(R D)$, and if the firm has cooperated in innovation projects with other agents like suppliers, research institutions and competitors (COOP), respectively. The reasoning for using COOP as instrument is based on the idea that firms benefit from knowledge spillovers due to cooperation. We expect these spillovers to increase the propensity to successfully develop new products which should in turn lead to higher expected new product sales. Furthermore, cooperating firms may benefit from their partners' distribution channels which might also be correlated with higher expected sales with new products. However, we do not expect this to significantly affect the relative price between old and new products. Some cooperation activities, e.g. related to the development of radical innovations, might indeed lead to higher prices while other cooperation activities, e.g. with suppliers, might be associated with lowering costs and prices of new products. Firms that continuously invest in R\&D $(R D)$ should likewise have a higher likelihood of inventing new technologies and as a result higher expected sales with new products. However, it is not necessarily the case that firms with continuous R\&D systematically charge higher prices for their new products than firms that discontinuously conduct $R \& D$ or innovate without any $R \& D$ activities.

The consistency of our IV estimates depends on the validity of instruments, i.e. the assumption that the instruments are uncorrelated with the error term. Therefore, we performed a Hansen $\mathrm{J}$ test on overidentifying restrictions for overall instrument validity and we used the difference-in-Hansen C statistic to test for exogeneity of a single instrument. It turned out that in high- and low-tech manufacturing RANGE and COOP are the only valid instruments for the total period and for all business cycle phases. For services, we likewise find RANGE and COOP to be valid instruments in KIS and LKIS for the overall period. However, when we split the sample by business cycle phases, only $R D$ and $C O O P$ passed the $\mathrm{C}$ test on instrument exogeneity.

We also checked for non-weakness of the instruments. Weak instruments can lead to a large relative finite-sample bias of IV compared to the bias of OLS (in case of endogenous explanatory variables). All 
first stage regressions show our valid instruments to be strongly correlated with the sales growth due to new products. Furthermore, the F-test of joint significance of the excluded instruments always yields a statistic clearly being larger than 10 . The regression output tables additionally display the KleibergenPaap LM test statistic on underidentification as well as the Kleibergen and Paap F test statistic on weak instruments (Kleibergen and Paap 2006). All these tests do not indicate our instruments to be weak.

As we are interested in studying reallocation dynamics, that is displacement and compensation effects of innovation at the sectoral level, we estimate equation (2) separately for the four sector groups and 16 industries. Furthermore, in order to investigate to what extent reallocation effects of innovation vary over the business cycle, we additionally split the sample into four business cycle periods: upturn, boom, downturn and recession (see Section 3).

A drawback of the created panel dataset is that individual firms cannot be tracked over time. This is not because CIS is simply a pooled cross sectional dataset consisting of random samples of different firms in different time periods. A considerable proportion of firms is repeatedly observed in the dataset due to three reasons. First, two countries (BG, MT) carry out the CIS as a census of all firms with 10 and more employees (target population). Second, in all other countries the CIS is at least a combination of a census of large firms and random sampling among small firms. The size threshold above which all firms are covered ranges from 50 employees (BE, EE, SI, IS, NO, HR) to 500 employees (DE) and is 250 employees for the majority of countries. Third, in some countries like Germany or Spain the random samples are also designed as a panel. Despite the fact that a considerable proportion of firms is repeatedly included in the dataset, we cannot exploit this information due to missing firm identifiers at Eurostat safecenter. As a result, we are not able to account for firm fixed effects in the empirical analysis but only employ pooled IV estimators assuming i.i.d. error terms. Given the fact that some firms are repeatedly observed, the i.i.d. assumption may be violated. We will address this in the following empirical analysis by using clustered standard errors at the industry-country level and hence allowing for correlation among the errors terms in the cluster.

\section{Regression Results}

Using equation (2), Table 2 reports regression results on the association between innovation and employment growth for four sector groups - HIGH, LOW, KIS and LKIS. Table 3 and Table 4 display the results for equation (2) when we additionally account for different phases of the business cycle - 
Table 3 for HIGH and LOW and Table 4 for KIS and LKIS. Table 9 in the Appendix finally presents results at the more disaggregated industry level. ${ }^{9}$

Recall, the dependent variable is $l-\left(g_{1}-\tilde{\pi}_{1}\right)$ where $l, g_{1}$ and $\tilde{\pi}_{1}$ are defined as employment growth, sales growth due to old products and price growth for old products where all growth rates are defined between $t$ and $t-2$. In addition to the central explanatory variables from equation (2), i.e. binary indicators for process innovation $(P C)$ and organisational innovation (ORGA) as well as sales growth rate due to new products between $t$ and $t-2, g_{2}$, (SGR_NEWPD), we add a number of control variables. The regression controls for foreign ownership captured by the two dummy variables DGP for domestic group firms and FGP for foreign-owned firms (reference group: domestic single firms). In order to control for differences in initial firm size in year t-2, two dummy variables are included: MEDIUM indicates firms with 50-249 employees and LARGE captures firms with 250+ employees. The reference group consists of small firms with 10-49 employees. Furthermore, country-specific two-year GDP growth rate (GDPGR), country dummies and time dummies as well as industry dummies for sector level regressions are included as controls. Information on foreign ownership and firm size is taken from the CIS. We include firm size because of the long-standing debate in economics if firm growth is dependent or independent of firm size (Sutton 1997). In the case of foreign ownership, Dachs and Peters (2014) recently showed that employment grows slower and is also more volatile in foreign-owned firms. GDP growth is included to reflect demand conditions in a particular country. Even if countries are in the same stage of the business cycle, they can differ in the growth rate of demand.

The coefficient of the sales growth rate due to new products, SGR_NEWPD, represents the gross effect of product innovation on employment. A value of one for the coefficient of SGR_NEWPD indicates that an increase in sales by one percent due to new products increases gross employment by one percent. A value for SGR_NEWPD of less than one implies that new products are produced with higher efficiency and thus less labour input than old products. Results reveal that this coefficient is significant and positive in all four sectors, in all four stages of the business cycle and in all $\mathbf{1 6}$ industries. This is a very strong indication for a positive relationship between employment and innovation and confirms previous results at the aggregate level also for the sector and industry level. However, a test if the coefficient for SGR_NEWPD is different from one yields no significant result in most cases (56 out of 64 samples). Only in less knowledge-intensive services we find new products to be produced with significantly higher efficiency and thus less labour input than old products. This result is largely driven by wholesale firms. We may therefore assume that the coefficient of SGR_NEWPD at industry and sector level as well as in different stages of the business cycle is mostly one or close to one. A number of arguments from the

9 We report results for 16 2-digit industries. We left out consultancies, other business related services and media due to insufficient number of observations. This is due to the fact that they do not belong to the core CIS industries (in all waves) and hence are not provided by all countries. 
literature presented in Section 2 would suggest a much greater heterogeneity in this coefficient with respect to the sectoral technology intensity. ${ }^{10}$

Overall, the regression results provide only little evidence for negative displacement effects of process innovation at the sector level. The strongest evidence is found for low-tech manufacturing where process innovation has a significantly negative coefficient for the whole period 1998-2010 and it turns out to be negative in all four business cycles though it is only significant in upturn and downturn phases (see Table 3). The results of Table 2 indicate that process innovators in low-tech manufacturing experience additional average efficiency gains of roughly $1.2 \%$ in two years, i.e. about $0.6 \%$ p.a. For high-tech manufacturing we also find negative displacement effects of similar magnitude but which are only significant in upturn periods. Displacement effects of process innovation are even less relevant in knowledge-intensive services and in less knowledge-intensive services where we could not find any significant effect, neither overall nor in different phases of the business cycle. This might be because firms may find it harder to identify process innovation in services as clear production processes are often not defined. Another reason could be that price level information at industry level is of lower quality in services than in manufacturing so that part of the price effect is captured by the process innovation and not by the industry price level. But finally it should also kept in mind that process innovation might not necessarily be introduced to reduce costs and labour but also to fulfil legal requirements or to increase product quality. The industry level results presented in Table 9 show that this pattern is very consistent across industries in these sector groups, with the exception of technical services.

10 We additionally test for the equality of the coefficients of SGR_NEWPD across samples in Table 2. For instance, the significance of the difference between the coefficients $\beta_{H}$ and $\beta_{L}$ in high- and low-tech manufacturing samples can be assessed with the statistic:

$z=\left(\hat{\beta}_{H}-\hat{\beta}_{L}\right) /\left[s_{\hat{\beta}_{u}}^{2}+s_{\hat{\beta}_{L}}^{2}\right]^{1 / 2}$ (see Clogg, Petkova and Haritou, 1995). Applying this to all sector combinations in Table 2, we do not find significant differences between the effect of SGR_NEWPD across sectors. 


\begin{tabular}{|c|c|c|c|c|}
\hline & HIGH & LOW & KIS & LKIS \\
\hline \multirow[t]{2}{*}{ SGR_NEWPD } & $0.999 * * *$ & $0.977 * * *$ & $0.969 * * *$ & $0.935^{* * *}$ \\
\hline & $(0.038)$ & $(0.019)$ & $(0.031)$ & $(0.030)$ \\
\hline \multirow[t]{2}{*}{ PC } & -1.026 & $-1.179 * *$ & -0.303 & -0.909 \\
\hline & $(0.693)$ & $(0.599)$ & $(1.474)$ & $(0.826)$ \\
\hline \multirow[t]{2}{*}{ ORGA } & $-1.454^{* *}$ & $-2.075^{* * *}$ & -0.989 & -0.425 \\
\hline & $(0.701)$ & $(0.488)$ & $(0.768)$ & $(0.5 .79)$ \\
\hline \multirow[t]{2}{*}{ MEDIUM } & $-2.365 * * *$ & $-1.291^{* * *}$ & $-4.028 * * *$ & $-3.361^{* * *}$ \\
\hline & $(0.862)$ & $(0.340)$ & $(0.837)$ & $(0.458)$ \\
\hline \multirow[t]{2}{*}{ LARGE } & $-4.256 * * *$ & $-2.982 * * *$ & $-5.181 * * *$ & $-4.375^{* * *}$ \\
\hline & $(0.978)$ & $(0.528)$ & $(1.036)$ & $(0.680)$ \\
\hline \multirow[t]{2}{*}{ DGP } & $1.393^{*}$ & $1.100^{*}$ & -0.275 & 0.445 \\
\hline & $(0.765)$ & $(0.640)$ & $(0.708)$ & $(0.645)$ \\
\hline \multirow[t]{2}{*}{ FGP } & 0.394 & -0.126 & -0.929 & $-1.701^{* *}$ \\
\hline & $(0.823)$ & $(0.554)$ & $(0.932)$ & $(0.834)$ \\
\hline \multirow[t]{2}{*}{ Constant } & $-22.334 * * *$ & $-21.032 * * *$ & $-16.986^{* * *}$ & $-8.912 * * *$ \\
\hline & $(2.238)$ & $(1.547)$ & $(4.455)$ & $(2.109)$ \\
\hline \multicolumn{5}{|l|}{ Wald test on joint significance } \\
\hline Industry & $0.026 * *$ & $0.000 * * *$ & $0.054^{*}$ & $0.000 * * *$ \\
\hline Country & $0.000 * * *$ & $0.000 * * *$ & $0.000 * * *$ & $0.000 * * *$ \\
\hline Time & $0.000 * * *$ & $0.000 * * *$ & $0.000 * * *$ & $0.000^{* * *}$ \\
\hline $\mathrm{R} 2 \mathrm{a}$ & 0.475 & 0.343 & 0.337 & 0.225 \\
\hline RMSE & 27.401 & 27.846 & 34.021 & 31.997 \\
\hline Wald-Test: $\beta=1$ & 0.986 & 0.212 & 0.318 & $0.031^{* *}$ \\
\hline \multicolumn{5}{|l|}{ Tests on Exogeneity (p-value) } \\
\hline SGR_NEWPD & $0.001 * * *$ & $0.000 * * *$ & $0.000 * * *$ & $0.015^{* *}$ \\
\hline \multicolumn{5}{|c|}{ Tests on Instrument validity ( $p$-value) } \\
\hline Sargan/Hansen J & 0.132 & 0.378 & 0.782 & $0.080 *$ \\
\hline \multicolumn{5}{|l|}{ First stage results } \\
\hline \multirow[t]{2}{*}{ RANGE } & $24.239 * * *$ & $22.501 * * *$ & $22.769 * * *$ & $23.602 * * *$ \\
\hline & $(1.023)$ & $(0.570)$ & ( 1.028$)$ & $(0.761)$ \\
\hline \multirow[t]{2}{*}{ COOP } & $6.595^{* * *}$ & $6.045^{* * *}$ & $12.111^{* * *}$ & $5.807 * * *$ \\
\hline & $(1.036)$ & $(0.600)$ & $(0.760)$ & $(0.880)$ \\
\hline F test on excluded instruments & $408.11^{* * *}$ & $782.72 * * *$ & $490.69 * * *$ & $692.00 * * *$ \\
\hline Partial R2 & 0.1868 & 0.1898 & 0.1671 & 0.2071 \\
\hline \multicolumn{5}{|l|}{ Tests on underidentification } \\
\hline Kleibergen-Paap LM test & $247.834 * * *$ & $710.633^{* * *}$ & $334.917 * * *$ & $1028.579 * * *$ \\
\hline \multicolumn{5}{|l|}{ Test on weak instruments } \\
\hline Kleibergen-Paap F test & $741.552 * * *$ & $1772.661 * * *$ & $1110.652 * * *$ & $692.002 * * *$ \\
\hline \multicolumn{5}{|l|}{ Weak instruments robust inference } \\
\hline Anderson-R. Wald test & $313.600 * * *$ & $1265.649 * * *$ & $573.485^{* * *}$ & $609.825 * * *$ \\
\hline Stock-Wright LM test & $25.959 * * *$ & $72.303^{* * *}$ & $49.495^{* * *}$ & $529.340^{* * *}$ \\
\hline Obs & 51,632 & 150,147 & 66,002 & 88,925 \\
\hline \multicolumn{5}{|c|}{ 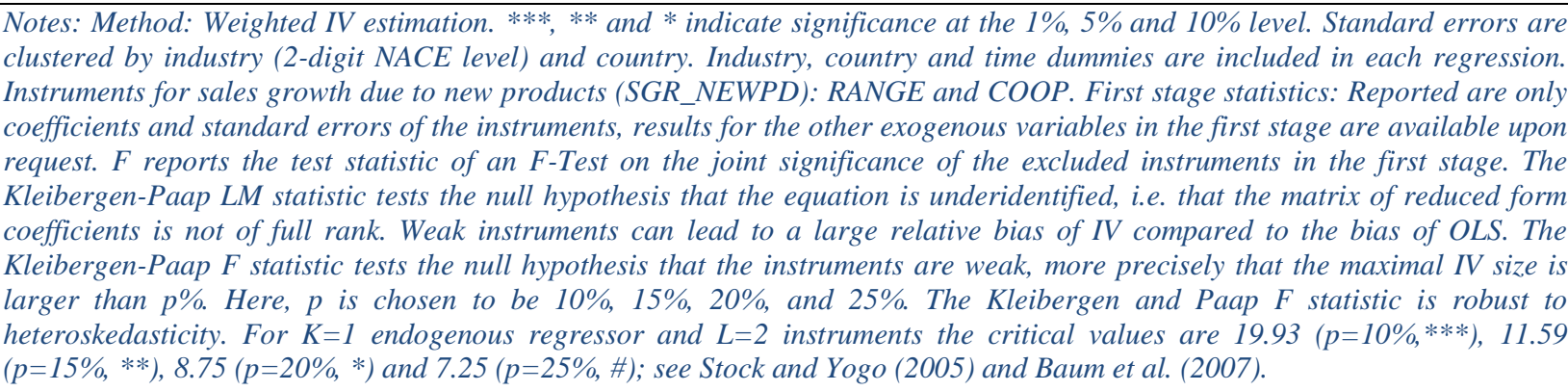 } \\
\hline
\end{tabular}




\begin{tabular}{|c|c|c|c|c|c|c|c|c|}
\hline & \multicolumn{4}{|c|}{ High-tech manufacturing } & \multicolumn{4}{|c|}{ Low-tech manufacturing } \\
\hline & Upturn & Boom & Downturn & Recession & Upturn & Boom & Downturn & Recession \\
\hline $\begin{array}{l}\text { SGR_NEWP } \\
\text { D }\end{array}$ & $\begin{array}{l}0.995 * * * \\
(0.034)\end{array}$ & $\begin{array}{l}0.964 * * * \\
(0.056)\end{array}$ & $\begin{array}{l}1.021^{* * *} \\
(0.055)\end{array}$ & $\begin{array}{l}0.993^{* * *} \\
(0.058)\end{array}$ & $\begin{array}{l}0.972 * * * \\
(0.027)\end{array}$ & $\begin{array}{l}0.970^{* * *} \\
(0.040)\end{array}$ & $\begin{array}{l}0.997 * * * \\
(0.027)\end{array}$ & $\begin{array}{l}0.955^{* * *} \\
(0.023)\end{array}$ \\
\hline PC & $\begin{array}{l}-2.813^{*} \\
(1.559)\end{array}$ & $\begin{array}{l}1.522 \\
(2.121)\end{array}$ & $\begin{array}{l}-1.408 \\
(1.649)\end{array}$ & $\begin{array}{l}0.568 \\
(2.478)\end{array}$ & $\begin{array}{l}-1.613^{*} \\
(0.930)\end{array}$ & $\begin{array}{l}-0.573 \\
(1.382)\end{array}$ & $\begin{array}{l}-1.921 * \\
(1.060)\end{array}$ & $\begin{array}{l}-0.634 \\
(1.100)\end{array}$ \\
\hline ORGA & $\begin{array}{l}-2.187^{* *} \\
(1.002)\end{array}$ & $\begin{array}{l}-0.430 \\
(1.684)\end{array}$ & $\begin{array}{l}-0.661 \\
(0.753)\end{array}$ & $\begin{array}{l}0.390 \\
(1.294)\end{array}$ & $\begin{array}{l}-2.131^{* * *} \\
(0.639)\end{array}$ & $\begin{array}{l}1.007 \\
(0.930)\end{array}$ & $\begin{array}{l}-1.553^{* *} \\
(0.743)\end{array}$ & $\begin{array}{l}-0.822^{* *} \\
(0.413)\end{array}$ \\
\hline GDPGR & $\begin{array}{l}2.351^{* *} \\
(0.979)\end{array}$ & $\begin{array}{l}-0.160 \\
(0.406)\end{array}$ & $\begin{array}{l}-0.171 \\
(0.248)\end{array}$ & $\begin{array}{l}0.173 \\
(0.523)\end{array}$ & $\begin{array}{l}3.849 * * * \\
(0.117)\end{array}$ & $\begin{array}{l}3.533^{* *} \\
(1.689)\end{array}$ & $\begin{array}{l}-0.722 * * * \\
(0.200)\end{array}$ & $\begin{array}{l}-0.045 \\
(0.314)\end{array}$ \\
\hline MEDIUM & $\begin{array}{l}-3.908^{* * *} \\
(1.007)\end{array}$ & $\begin{array}{l}1.022 \\
(2.161)\end{array}$ & $\begin{array}{l}-2.283 \\
(1.466)\end{array}$ & $\begin{array}{l}-3.285^{* * *} \\
(0.762)\end{array}$ & $\begin{array}{l}-2.836 * * * \\
(0.468)\end{array}$ & $\begin{array}{l}-0.398 \\
(0.884)\end{array}$ & $\begin{array}{l}-1.037 \\
(0.639)\end{array}$ & $\begin{array}{l}-1.721^{* * *} \\
(0.561)\end{array}$ \\
\hline LARGE & $\begin{array}{l}-5.639 * * * \\
(1.018)\end{array}$ & $\begin{array}{l}-2.986 \\
(2.407)\end{array}$ & $\begin{array}{l}-2.671 \\
(1.802)\end{array}$ & $\begin{array}{l}-5.526^{* * *} \\
(1.061)\end{array}$ & $\begin{array}{l}-4.247 * * * \\
(0.637)\end{array}$ & $\begin{array}{l}-3.813^{* * *} \\
(1.139)\end{array}$ & $\begin{array}{l}-1.079 \\
(0.883)\end{array}$ & $\begin{array}{l}-3.490 * * * \\
(0.762)\end{array}$ \\
\hline DGP & $\begin{array}{l}-1.838^{* *} \\
(0.919)\end{array}$ & $\begin{array}{l}4.824 * * * \\
(1.623)\end{array}$ & $\begin{array}{l}-0.386 \\
(1.711)\end{array}$ & $\begin{array}{l}3.543 * * * \\
(1.134)\end{array}$ & $\begin{array}{l}-1.243 \\
(0.828)\end{array}$ & $\begin{array}{l}2.559 * * \\
(1.163)\end{array}$ & $\begin{array}{l}0.836 \\
(0.707)\end{array}$ & $\begin{array}{l}0.340 \\
(0.640)\end{array}$ \\
\hline FGP & $\begin{array}{l}-0.007 \\
(1.275)\end{array}$ & $\begin{array}{l}2.216 \\
(1.716)\end{array}$ & $\begin{array}{l}-0.448 \\
(1.306)\end{array}$ & $\begin{array}{l}-1.152 \\
(0.949)\end{array}$ & $\begin{array}{l}-1.736 \\
(1.077)\end{array}$ & $\begin{array}{l}0.474 \\
(1.261)\end{array}$ & $\begin{array}{l}0.550 \\
(0.836)\end{array}$ & $\begin{array}{l}-2.007 * * \\
(0.817)\end{array}$ \\
\hline Constant & $\begin{array}{l}-53.550^{* * *} \\
(12.328) \\
\end{array}$ & $\begin{array}{l}-9.650^{* *} \\
(4.889) \\
\end{array}$ & $\begin{array}{l}-20.328^{* * *} \\
(4.045)\end{array}$ & $\begin{array}{l}-0.632 \\
(2.673) \\
\end{array}$ & $\begin{array}{l}-69.290 * * * \\
(2.005)\end{array}$ & $\begin{array}{l}-39.935 * * * \\
(15.156)\end{array}$ & $\begin{array}{l}-14.044^{* * *} \\
(3.063)\end{array}$ & $\begin{array}{l}3.554^{*} \\
(1.875)\end{array}$ \\
\hline \multicolumn{9}{|c|}{ Wald test on joint significance } \\
\hline Industry & $0.000 * * *$ & 0.538 & $0.000 * * *$ & $0.000 * * *$ & $0.000 * * *$ & $0.000 * * *$ & $0.000^{* * *}$ & $0.000 * * *$ \\
\hline Country & $0.000^{* * * *}$ & $0.000 * * *$ & $0.000 * * *$ & $0.000 * * *$ & $0.000^{* * *}$ & $0.000^{* * *}$ & $0.000 * * *$ & $0.000 * * *$ \\
\hline Time & $0.000^{* * *}$ & $0.003^{* * *}$ & $0.001^{* * *}$ & - & $0.000^{* * *}$ & - & $0.000^{* * *}$ & - \\
\hline $\mathrm{R} 2 \mathrm{a}$ & 0.436 & 0.534 & 0.458 & 0.582 & 0.359 & 0.466 & $\begin{array}{l}0.369 \\
29002\end{array}$ & $\begin{array}{l}0.406 \\
20.890\end{array}$ \\
\hline $\begin{array}{l}\text { RMSE } \\
\text { Wald-Test: } \\
\beta=1\end{array}$ & $\begin{array}{l}29.759 \\
0.892 \\
\end{array}$ & $\begin{array}{l}25.048 \\
0.527 \\
\end{array}$ & $\begin{array}{l}28.290 \\
0.709 \\
\end{array}$ & $\begin{array}{l}21.308 \\
0.908 \\
\end{array}$ & $\begin{array}{l}29.740 \\
0.293 \\
\end{array}$ & $\begin{array}{l}23.027 \\
0.446 \\
\end{array}$ & $\begin{array}{l}29.002 \\
0.914 \\
\end{array}$ & $\begin{array}{l}20.890 \\
0.054 *\end{array}$ \\
\hline $\begin{array}{l}\text { Tests on Exoge } \\
\text { SGR_NEWP } \\
\text { D }\end{array}$ & $\begin{array}{l}\text { ity (p-value) } \\
0.005^{* * *}\end{array}$ & 0.330 & $0.015^{* *}$ & 0.111 & $0.000 * * *$ & $0.011^{* *}$ & $0.000 * * *$ & $0.058^{*}$ \\
\hline $\begin{array}{l}\text { Tests on Instru } \\
\text { Sargan/ } \\
\text { Hansen J }\end{array}$ & $\begin{array}{l}\text { ent validity }(p- \\
0.216\end{array}$ & $\begin{array}{l}\text { alue) } \\
0.157 \\
\end{array}$ & 0.613 & 0.325 & 0.511 & 0.555 & 0.166 & 0.693 \\
\hline \multicolumn{9}{|c|}{ First stage results } \\
\hline RANGE & $\begin{array}{l}25.821^{* * *} \\
(1.564)\end{array}$ & $\begin{array}{l}24.914^{* * *} \\
(1.574)\end{array}$ & $\begin{array}{l}22.689^{* * *} \\
(1.218)\end{array}$ & $\begin{array}{l}20.919 * * * \\
(2.200)\end{array}$ & $\begin{array}{l}23.436^{* * *} \\
(0.856)\end{array}$ & $\begin{array}{l}21.675^{* * *} \\
(1.031)\end{array}$ & $\begin{array}{l}24.034^{* * *} \\
(1.047)\end{array}$ & $\begin{array}{l}20.446^{* * *} \\
(1.037)\end{array}$ \\
\hline COOP & $\begin{array}{l}6.780^{* * *} \\
(1.478)\end{array}$ & $\begin{array}{l}8.281^{* * *} \\
(2.763)\end{array}$ & $\begin{array}{l}7.694 * * * \\
(0.932)\end{array}$ & $\begin{array}{l}5.359 * * * \\
(1.619)\end{array}$ & $\begin{array}{l}7.226 * * * \\
(' 1.052)\end{array}$ & $\begin{array}{l}5.244 * * * \\
(1.956)\end{array}$ & $\begin{array}{l}6.643 * * * \\
(0.883)\end{array}$ & $\begin{array}{l}3.324^{* * *} \\
(0.881)\end{array}$ \\
\hline $\begin{array}{l}\text { F test on } \\
\text { excluded instr. } \\
\text { Partial R2 }\end{array}$ & $\begin{array}{l}218.00^{* * *} \\
0.1931\end{array}$ & $\begin{array}{l}177.45^{* * *} \\
0.2093\end{array}$ & $\begin{array}{l}373.32 * * * \\
0.1992\end{array}$ & $\begin{array}{l}114.21^{* * *} \\
0.1592\end{array}$ & $\begin{array}{l}589.95^{* * *} \\
0.1751\end{array}$ & $\begin{array}{l}231.98^{* * *} \\
0.1854\end{array}$ & $\begin{array}{l}290.3^{* * *} \\
0.1987\end{array}$ & $\begin{array}{l}282.51^{* * *} \\
0.2122\end{array}$ \\
\hline $\begin{array}{l}\text { Tests on under } \\
\text { Kleibergen- } \\
\text { Paap LM test }\end{array}$ & $\begin{array}{l}\text { entification } \\
105.51^{* * *}\end{array}$ & $14.48^{* * *}$ & $321.76^{* * *}$ & $119.56^{* * *}$ & $807.92^{* * *}$ & $358.01 * * *$ & $964.58^{* * *}$ & $726.33^{* * *}$ \\
\hline $\begin{array}{l}\text { Test on weak ir } \\
\text { Kleibergen- } \\
\text { Paap F test }\end{array}$ & $\begin{array}{l}\text { ruments. } \\
373.04^{* * *}\end{array}$ & $255.53 * * *$ & $268.40 * * *$ & $82.36 * * *$ & $589.95 * * *$ & $231.98^{* * *}$ & $943.38 * * *$ & $521.09 * * *$ \\
\hline $\begin{array}{l}\text { Weak instrume } \\
\text { Anderson-R. } \\
\text { Wald test } \\
\text { Stock-Wright } \\
\text { LM test }\end{array}$ & $\begin{array}{l}\text { s robust infere } \\
309.57^{* * *}\end{array}$ & $211.05^{* * *}$ & $262.38 * * *$ & $101.16^{* * *}$ & $743.60 * * *$ & $301.04 * * *$ & $626.49 * * *$ & $408.91^{* * *}$ \\
\hline Obs & 18,407 & 5,097 & 15,489 & 12,632 & 49,163 & 10,771 & 52,243 & 39,208 \\
\hline $\begin{array}{l}\text { Notes: See T } \\
\text { (due to a sing } \\
\text { clustered reg } \\
\text { COOP in orc } \\
\text { important inf }\end{array}$ & $\begin{array}{l}\text { 2. Robus } \\
\text { on dummy } \\
\text { sion). In th } \\
\text { to ensure } i \\
\text { ation sour }\end{array}$ & $\begin{array}{l}\text { stead of } \\
\text { iables pr } \\
\text { downturn } \\
\text { rument vo } \\
\text { for innova }\end{array}$ & $\begin{array}{l}\text { red stand } \\
n \text { the estim } \\
\text { od for hig } \\
\text {. CLIENT }\end{array}$ & $\begin{array}{l}\text { errors ar } \\
\text { covarian } \\
\text { ch manuf } \\
\text { binary } v\end{array}$ & $\begin{array}{l}\text { orted for } \\
\text { atrix of } n \\
\text { ring CLIE } \\
\text { le that ec }\end{array}$ & $\begin{array}{l}\text { rn and bc } \\
\text { nt conditi } \\
\text { has been } \\
1 \text { if clien }\end{array}$ & $\begin{array}{l}\text { in low-tech } \\
\text { were not of } \\
d \text { as instru } \\
\text { ave been a }\end{array}$ & $\begin{array}{l}\text { anufacturing } \\
\text { I rank in the } \\
\text { it instead of } \\
\text { h-to-medium }\end{array}$ \\
\hline
\end{tabular}


Table 4: Impact of innovation on employment growth over the business cycle in knowledgeintensive and less knowledge-intensive services

\begin{tabular}{|c|c|c|c|c|c|c|c|c|}
\hline & \multicolumn{4}{|c|}{ Knowledge-intensive services (KIS) } & \multicolumn{4}{|c|}{ Less knowledge-intensive services (LKIS) } \\
\hline & Upturn & Boom & Downturn & Recession & Upturn & Boom & Downturn & Recession \\
\hline SGR_NEWPD & $\begin{array}{l}0.956 * * * \\
(0.051)\end{array}$ & $\begin{array}{l}0.996 * * * \\
(0.086)\end{array}$ & $\begin{array}{l}0.965^{* * *} \\
(0.041)\end{array}$ & $\begin{array}{l}1.001^{* * * *} \\
(0.037)\end{array}$ & $\begin{array}{l}1.037 * * * \\
(0.101)\end{array}$ & $\begin{array}{l}0.867 * * * \\
(0.093)\end{array}$ & $\begin{array}{l}1.104^{* * *} \\
(0.100)\end{array}$ & $\begin{array}{l}1.060^{* * *} \\
(0.084)\end{array}$ \\
\hline PC & $\begin{array}{l}-2.454 \\
(2.324)\end{array}$ & $\begin{array}{l}7.958 \\
(7.408)\end{array}$ & $\begin{array}{l}0.573 \\
(1.309)\end{array}$ & $\begin{array}{l}-1.992 \\
(1.471)\end{array}$ & $\begin{array}{l}0.774 \\
(2.126)\end{array}$ & $\begin{array}{l}-4.282 \\
(3.685)\end{array}$ & $\begin{array}{l}1.587 \\
(1.709)\end{array}$ & $\begin{array}{l}1.021 \\
(1.085)\end{array}$ \\
\hline ORGA & $\begin{array}{l}-1.903 \\
(1.320)\end{array}$ & $\begin{array}{l}-4.599 * * \\
(1.975)\end{array}$ & $\begin{array}{l}-1.826^{* *} \\
(0.916)\end{array}$ & $\begin{array}{l}2.642 * * * \\
(0.824)\end{array}$ & $\begin{array}{l}-2.283^{* *} \\
(0.956)\end{array}$ & $\begin{array}{l}2.555 \\
(2.132)\end{array}$ & $\begin{array}{l}-1.358 \\
(1.487)\end{array}$ & $\begin{array}{l}-1.353 * * \\
(0.557)\end{array}$ \\
\hline GDPGR & $\begin{array}{l}3.285^{* * *} \\
(1.197)\end{array}$ & $\begin{array}{l}-9.420 * * \\
(3.988)\end{array}$ & $\begin{array}{l}-0.334 \\
(0.387)\end{array}$ & $\begin{array}{l}0.902 \\
(0.566)\end{array}$ & $\begin{array}{l}1.297 \\
(2.827)\end{array}$ & $\begin{array}{l}-0.518 \\
(2.401)\end{array}$ & $\begin{array}{l}-0.668 * * * \\
(0.258)\end{array}$ & $\begin{array}{l}0.932 * * * \\
(0.220)\end{array}$ \\
\hline MEDIUM & $\begin{array}{l}-6.298 * * * \\
(1.272)\end{array}$ & $\begin{array}{l}2.204 \\
(3.901)\end{array}$ & $\begin{array}{l}-4.333^{* * *} \\
(1.049)\end{array}$ & $\begin{array}{l}-3.208^{* * *} \\
(0.901)\end{array}$ & $\begin{array}{l}-3.298^{* * *} \\
(1.207)\end{array}$ & $\begin{array}{l}-1.650 \\
(1.877)\end{array}$ & $\begin{array}{l}-2.784 * * * \\
(0.800)\end{array}$ & $\begin{array}{l}-4.903^{* * *} \\
(0.745)\end{array}$ \\
\hline LARGE & $\begin{array}{l}-6.778^{* * *} \\
(2.152)\end{array}$ & $\begin{array}{l}0.687 \\
(2.747)\end{array}$ & $\begin{array}{l}-7.541^{* * *} \\
(1.990)\end{array}$ & $\begin{array}{l}-2.978 * \\
(1.740)\end{array}$ & $\begin{array}{l}-2.034 \\
(1.921)\end{array}$ & $\begin{array}{l}-5.710 * * \\
(2.810)\end{array}$ & $\begin{array}{l}-4.228 * * * \\
(1.080)\end{array}$ & $\begin{array}{l}-6.929 * * * \\
(1.199)\end{array}$ \\
\hline DGP & $\begin{array}{l}-1.828 \\
(1.779)\end{array}$ & $\begin{array}{l}1.150 \\
(1.790)\end{array}$ & $\begin{array}{l}-1.135 \\
(0.907)\end{array}$ & $\begin{array}{l}-0.110 \\
(1.172)\end{array}$ & $\begin{array}{l}-0.347 \\
(1.274)\end{array}$ & $\begin{array}{l}-0.126 \\
(2.575)\end{array}$ & $\begin{array}{l}0.743 \\
(0.862)\end{array}$ & $\begin{array}{l}0.735 \\
(0.694)\end{array}$ \\
\hline FGP & $\begin{array}{l}-4.632 * * \\
(2.278)\end{array}$ & $\begin{array}{l}0.490 \\
(2.707)\end{array}$ & $\begin{array}{l}0.987 \\
(1.332)\end{array}$ & $\begin{array}{l}0.032 \\
(1.383)\end{array}$ & $\begin{array}{l}-5.287 * * * \\
(1.676)\end{array}$ & $\begin{array}{l}-3.215 \\
(3.304)\end{array}$ & $\begin{array}{l}-0.371 \\
(1.071)\end{array}$ & $\begin{array}{l}0.336 \\
(1.187)\end{array}$ \\
\hline Constant & $\begin{array}{l}-53.700^{* * *} \\
(16.929) \\
\end{array}$ & $\begin{array}{l}59.986 * \\
(32.270) \\
\end{array}$ & $\begin{array}{l}-14.326 * * \\
(5.708) \\
\end{array}$ & $\begin{array}{l}16.192^{* * *} \\
(3.266)\end{array}$ & $\begin{array}{l}-25.715 \\
(34.288) \\
\end{array}$ & $\begin{array}{l}-6.706 \\
(20.136) \\
\end{array}$ & $\begin{array}{l}-5.479 \\
(4.384) \\
\end{array}$ & $\begin{array}{l}15.024^{* * *} \\
(1.488)\end{array}$ \\
\hline \multicolumn{9}{|c|}{ Wald test on joint significance } \\
\hline Industry & 0.189 & 0.515 & $0.007 * * *$ & 0.307 & 0.311 & 0.247 & $0.000^{* * *}$ & $0.001^{* * *}$ \\
\hline Country & $0.000 * * *$ & $0.000 * * *$ & $0.000 * * *$ & $0.000 * * *$ & $0.000 * * *$ & $0.000 * * *$ & $0.000 * * *$ & $0.000 * * *$ \\
\hline Time & $0.004 * * *$ & - & 0.334 & - & $0.086^{*}$ & - & 0.605 & - \\
\hline $\mathrm{R} 2 \mathrm{a}$ & 0.294 & 0.412 & 0.338 & 0.438 & 0.185 & 0.306 & 0.233 & 0.295 \\
\hline RMSE & 37.127 & 36.549 & 36.452 & 24.652 & 37.175 & 29.477 & 34.363 & 22.823 \\
\hline Wald-Test: $\beta=1$ & 0.387 & 0.962 & 0.392 & 0.984 & 0.712 & 0.154 & 0.297 & 0.477 \\
\hline \multicolumn{9}{|c|}{ Tests on Exogeneity (p-value) } \\
\hline SGR_NEWPD & $0.001 * * *$ & 0.451 & $0.000 * * *$ & $0.072 *$ & $0.056 *$ & 0.805 & $0.023 * *$ & $0.038 * *$ \\
\hline $\begin{array}{l}\text { Tests on Instrum } \\
\text { Sargan/ } \\
\text { Hansen J }\end{array}$ & $\begin{array}{l}t \text { validity }(p-v \\
0.656\end{array}$ & 0.230 & 0.898 & 0.236 & 0.256 & 0.675 & 0.477 & 0.574 \\
\hline \multicolumn{9}{|c|}{ First stage results } \\
\hline $\mathrm{RD}$ & $\begin{array}{l}24.178^{* * *} \\
(2.523)\end{array}$ & $\begin{array}{l}23.038 * * * \\
(4.364)\end{array}$ & $\begin{array}{l}19.424 * * * \\
(1.450)\end{array}$ & $\begin{array}{l}18.534 * * * \\
(1.476)\end{array}$ & $\begin{array}{l}17.234 * * * \\
(2.950)\end{array}$ & $\begin{array}{l}25.871 * * * \\
(2.332)\end{array}$ & $\begin{array}{l}15.298 * * * \\
(2.499)\end{array}$ & $\begin{array}{l}14.995^{* * *} \\
(2.584)\end{array}$ \\
\hline COOP & $\begin{array}{l}15.728^{* * *} \\
(1.048)\end{array}$ & $\begin{array}{l}14.493^{* * *} \\
(3.543)\end{array}$ & $\begin{array}{l}22.414 * * * \\
(1.458)\end{array}$ & $\begin{array}{l}12.227 * * * \\
(1.111)\end{array}$ & $\begin{array}{l}14.610^{* * *} \\
(1.630)\end{array}$ & $\begin{array}{l}4.468 \\
(3.195)\end{array}$ & $\begin{array}{l}13.262 * * * \\
(1.412)\end{array}$ & $\begin{array}{l}10.948 * * * \\
(1.500)\end{array}$ \\
\hline $\begin{array}{l}\text { F test on } \\
\text { excluded instr. }\end{array}$ & $218.94 * * *$ & $70.60 * * *$ & $241.48^{* * *}$ & $221.65^{* * *}$ & $58.79 * * *$ & $83.54^{* * *}$ & $53.48 * * *$ & $41.66^{* * *}$ \\
\hline Partial R2 & 0.1410 & 0.0974 & 0.1722 & 0.1545 & 0.0796 & 0.2572 & 0.0489 & 0.0605 \\
\hline $\begin{array}{l}\text { Tests on underid } \\
\text { Kleibergen- } \\
\text { Paap LM test }\end{array}$ & $\begin{array}{l}\text { tification } \\
209.90 * * * \\
\end{array}$ & $7.25^{* *}$ & $732.28 * * *$ & $261.28 * * *$ & $106.59 * * *$ & $115.68 * * *$ & $178.35^{* * *}$ & $87.23^{* * *}$ \\
\hline $\begin{array}{l}\text { Test on weak ins } \\
\text { Kleibergen- } \\
\text { Paap F test } \\
\text { Partial R2 }\end{array}$ & $\begin{array}{l}\text { Iments. } \\
\text { 228.92*** }\end{array}$ & $81.59 * * *$ & $548.30 * * *$ & $177.58 * * *$ & $102.16^{* * *}$ & $83.55^{* * *}$ & $66.12^{* * *}$ & $60.08 * * *$ \\
\hline $\begin{array}{l}\text { Weak instrument } \\
\text { Anderson-R. } \\
\text { Wald test } \\
\text { Stock-Wright } \\
\text { LM test }\end{array}$ & $\begin{array}{l}\text { obust inferen } \\
183.94 * * * \\
29.79 * * *\end{array}$ & $\begin{array}{l}74.30 * * * \\
7.72 * *\end{array}$ & $\begin{array}{l}343.78^{* * *} \\
49.27^{* * *}\end{array}$ & $\begin{array}{l}268.62 * * * \\
34.16 * * *\end{array}$ & $\begin{array}{l}162.47^{* * *} \\
14.08^{* * *}\end{array}$ & $\begin{array}{l}54.02 * * * \\
48.39 * * *\end{array}$ & $\begin{array}{l}122.43 * * * \\
16.77 * * *\end{array}$ & $\begin{array}{l}250.14 * * * \\
21.08 * * *\end{array}$ \\
\hline Obs & 20,518 & 4,226 & 20,424 & 21,157 & 24,833 & 3,741 & 32,738 & 26,121 \\
\hline
\end{tabular}


The analysis reveals stronger displacement effects for organisational innovation (ORGA). ORGA has a significantly negative effect on employment in both high-tech and low-tech manufacturing firms. Employment growth decreases by about $2.1 \%$ for organisational innovators in low-tech manufacturing in two years, and the effect is similarly strong for high-tech manufacturing firms (-1.4\%). In high-tech manufacturing, organisational innovation is particularly employment-destructive in upturns phases. The results also show negative coefficients for ORGA in knowledge-intensive services and in less knowledgeintensive services which are, however, not significant for the whole period. ${ }^{11}$ The reason is that the sign and magnitude of organisational innovation varies quite a lot over the business cycle in KIS and LKIS. Most striking is the finding that in the recession organisational innovations have been associated with labour displacement in less knowledge-intensive service firms whereas knowledge-intensive service firms which have reorganised their business processes in the recession period perform significantly better in terms of employment growth. The size of the coefficients suggests that organisational innovation has a higher employment-destroying potential in KIS than in LKIS, and in services than in manufacturing (when splitting the sample by business cycles).

Note, in the model the constant is the average real productivity gain and thus change in labour input that is not related to any innovation activity (general productivity trend). As the estimation additionally includes industry dummies, time dummies, size dummies, country dummies and is estimated for different business cycles, the constant in the regression tables represent the employment effect of the reference group. For each regression, it refers to the group of small firms that are not part of an enterprise group that belongs to one specific industry and country observed at one specific period. That is, the constant can refer to different types of firms/countries, which makes the comparability across regressions more difficult. The decomposition analysis in the next section provides a comprehensible estimate of the contribution of the general productivity trend to employment growth.

With respect to the control variables we find the expected results for firm size. Larger and medium-sized firms exhibit smaller employment growth than small firms with 10-49 employees in all sector groups. With respect to foreign ownership, however, no consistent pattern across sector groups emerges.

\section{Employment decomposition}

A decomposition analysis at the sector and industry level complements the quantitative analysis. This allows us to disentangle the employment effects of product, process and organisational innovations from

11 The effect of organisational innovation is significantly larger in low-tech manufacturing than in knowledge-intensive services (p-value: 0.0312), whereas the difference is only marginally significant (p-value: 0.1163) between low-tech manufacturing and less knowledgeintensive services. 
effects originating from general demand and productivity trends (Harrison et al, 2014). Based on the regression results, we can rewrite employment growth for each firm as:

(3) $l=\underbrace{\hat{\alpha}_{0}}_{1}+\underbrace{\hat{\alpha}_{1} p c}_{2}+\underbrace{\hat{\alpha}_{2} \text { orga }}_{3}+\underbrace{\left[1-I\left(g_{2}>0\right)\right]\left(g_{1}-\tilde{\pi}_{1}\right)}_{4}+[\underbrace{I\left(g_{2}>0\right)\left(g_{1}-\tilde{\pi}_{1}\right)}_{5 a}+\underbrace{I\left(g_{2}>0\right) \beta g_{2}}_{5 b}]+\underbrace{\hat{\varepsilon}}_{6}$

The first term, $\hat{\alpha}_{0}$, measures the contribution of the general productivity trend in the production of old products to employment growth. It accounts for all changes in efficiency and as a result in employment that are not attributable to the firms' own innovations in period $t$ to $t$-2. For instance, $\hat{\alpha}_{0}$ may capture efficiency gains due improvements in management practices, sales of unprofitable business units, training, improvements in the human capital endowment, in industrial relations, or productivity effects from spillovers. Some of these sources, like training, may stimulate own innovation - an effect that is captured by the innovation variable. But, training may also lead to efficiency gains unrelated to any innovation activities. For instance, better trained employees may also be more able to use existing technologies (like IT) more efficiently than before the training - an effect that would be captured by $\hat{\alpha}_{0}$. The general productivity trend is calculated in a way that it is industry-, country-, time-, size- and ownership-specific, since it captures not only the effect of the estimated constant but also of the corresponding dummy variables and changes of GDP growth. It is measured as the average effect across innovators and non-innovators.

The second and the third terms capture the labour displacement effects of process innovations and organisational innovations. Note the first three terms will be summed up into one factor in figures below.

In equation (3) $I($.$) denotes an indicator function. It takes on the value one if the condition in parentheses$ is true and zero otherwise. That is, $I\left(g_{2}>0\right)$ refers to product innovators, while $1-I\left(g_{2}>0\right)$ refers to non-product innovators. This implies that the fourth component measures changes in employment growth that are caused by the real growth of the output of old products for firms that have not implemented product innovations. Recall, a demand increase of old products can be due to a change in consumers' preferences, price reductions but also because of rivals' product innovations (business stealing effect). In contrast to equation (1), we capture the cannibalisation effect by the term $5 \mathrm{a}$, while $5 \mathrm{~b}$ includes the gross contribution of product innovation, output growth due to new products. In sum the components $5 \mathrm{a}$ and $5 \mathrm{~b}$ measure the net contribution of product innovation to employment growth. The net contribution of product innovation to employment growth effect depends on (i) the demand increase for new products $g_{2}$, (ii) the relative production efficiency between old and new products, $\hat{\beta}$ and (iii) possible shifts in demand for the old products, $\left(g_{1}-\tilde{\pi}_{1}\right)$. The latter effect captures cannibalisation effects if $\left(g_{1}-\tilde{\pi}_{1}\right)<0$ and complementarity effects to the innovator's own old products if $\left(g_{1}-\tilde{\pi}_{1}\right)>0$, respectively. 
Averaging equation (3) across all firms in a sector provides the decomposition of the average employment growth at the sector level. We obtain the decomposition by inserting into the equation the estimated

coefficients $\hat{\alpha}_{0}, \hat{\alpha}_{1}, \hat{\alpha}_{2}$, and $\hat{\beta}$, the weighted sector shares of non-innovators, process, organisational and product innovators and weighted sector averages for employment, price and sales growth rates (either for the total firms in a sector or for the corresponding group of firms). A corresponding approach is used for the industry level.

\section{Decomposition at Sectoral Level}

Figure 2 below illustrates the results of the decomposition for the four sectors over the period 1998-2010. For ease of representation, we have summarised the employment effects due to general productivity gains, process and organisational innovation, i.e. the terms (1) to (3), into one bar. A detailed decomposition is given in Table 5. The other three bars show

- the employment effects from old products for non-product innovators, which include business stealing between product innovators and non-product innovators,

- the gross effect of product innovation which includes employment growth due to products the firm has introduced to the market in the current period,

- employment effects from old products for product innovators, which include intra-firm complementarity and cannibalisation effects between new and old products but also inter-firm business stealing between innovative firms.

The sum of the latter two effects is the net effect of product innovation. All four components sum up to the (weighted) average two-year employment growth, which is depicted below by the horizontal axis. The size of the bars reflects the contribution of each component to employment growth in percentage points.

The decomposition analysis shows that in high-tech manufacturing, firms have experienced sizeable efficiency gains in the production of existing technologies which would have led to a decline in employment by about 2.3 percent. These losses have been compensated by an increase in demand for old products by 2.9 percent. The most important driver for employment, however, has been product innovation. Employment growth due to sales generated with new products has been 15.7 percent. Even taking cannibalisation effects between new and old products and inter-firm business stealing between innovative firms into account (-12.5 percent), the net contribution of product innovation has been positive (3.2 percent) and even larger than for old products. It turns out that the displacement and compensation effects of product innovation and also its net effect are roughly twice as large in high-tech manufacturing compared to low-tech manufacturing. The same pattern of increasing displacement and compensation effects with increasing sectoral technological intensity is observed in services, which is in favour of our hypothesis H1. We also observe that displacement and compensation effects of product innovations are 
higher in high-tech manufacturing than in knowledge-intensive services and higher in low-tech manufacturing than in less knowledge-intensive services which supports our hypothesis H2. Note, however, that the net effect of product innovation is very similar in HIGH and KIS on the one hand and LOW and LKIS on the other hand.

Figure 2 : Decomposition of employment growth by sector groups

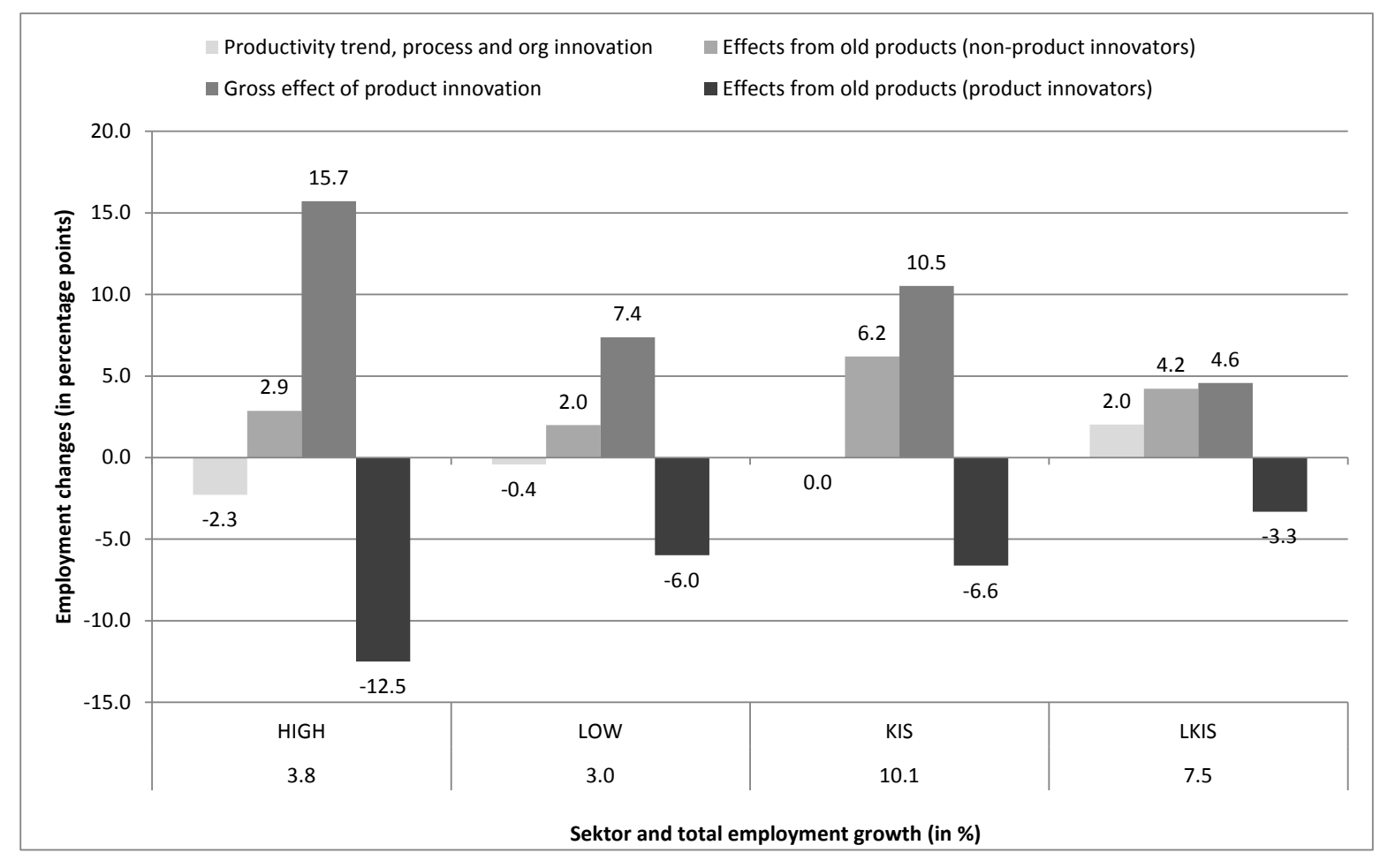

Notes: Decomposition of the weighted average two-year employment growth rate across all firms in a given sector. Source: CIS3, CIS4, CIS2006, CIS2008 and CIS2010, Eurostat; own calculation.

Table 5 furthermore show that displacement effects due to organisational innovation are stronger in manufacturing than in services. In services displacement effects due to organisational innovation are stronger KIS than in LKIS whereas we do not observe larger differences by sectoral technology intensity in manufacturing. Displacement effects of process innovation are small in all four sector groups.

Figure 3 and Table 5 additionally show to what extent these employment contributions at the sector level differ over the business cycle. In upturns, product innovation is again the biggest driver of employment growth in all sectors - except for less knowledge-intensive services - followed by the contribution of demand for old products for non-innovators. The positive compensation effect of product innovation is larger in sectors with higher technological intensity. But in line with $\mathrm{H} 1$ we also see that negative externalities for product innovators are highest in high-tech manufacturing, being almost twice the absolute size of total employment growth. In all four sectors, job losses due to process- and organisational innovation and general productivity increases as well as the losses innovators suffer from fewer sales with their old products can be compensated by employment growth originating from demand increases for old 
products by non-innovators and by new demand related to product innovation. The patterns for manufacturing and services look similar, apart from the fact that average employment growth is higher in services. We can explain this by lower negative externalities from product innovation in services and a higher contribution of old products. The contribution of product innovation, in contrast, is lower in services. Both observations support H2.

The general pattern of compensation and displacement effects observed during an upturn changes only little when we look at sectoral employment drivers during an economic boom, despite the fact that overall employment growth and the contribution of product innovation is higher during a boom. This reflects increases in income of demanding firms and consumers and positive expectations of future demand by innovating firms. The largest difference in the contribution of product innovation can be seen in knowledge-intensive services, reflecting more open markets for these services. The contribution of product innovation in KIS even excels that in high-tech manufacturing, which questions the notion of less economic applications for new technologies in services. Moreover, we see higher employment losses in KIS from organisational innovation and the general productivity trend. The latter may indicate that measures taken by firms during a recession or upturn to improve productivity have a certain time lag and unfold their full potential only in the next stage of the business cycle. Since we cannot follow individual firms over time with the data at hand, we leave this question for future research.

The pattern of employment growth in an economic downturn resembles those in an upturn and boom. Firms in all four sectors can compensate the displacement effects due to general productivity increases, process and organisational innovation by the positive compensation effects of new products. The gap between these displacement and compensation effects is highest in high-tech manufacturing.

Demand for existing old products relative to new products contributes more to overall average employment growth in service firms than in manufacturing firms, leading to a higher overall average employment growth in service firms. This is the biggest difference between manufacturing and services in our analysis. As stated in Section 2, service products are more often the result of user-producer interaction than standardised manufacturing products which may reduce the need to exchange old for new products. The higher degree of customisation, together with a slower pace of technological change in service sectors, may explain the larger contribution of old products. In less knowledge-intensive services, new products contribute less than old products in all three business cycle phases (upturn, boom and downturn). Knowledge-intensive services are more similar to manufacturing. Whereas the gross demand effect of new products is similar to the demand effect of old products in up- and downturns, the net employment contribution of new products turned out to be lower in this sector except for the boom period. 


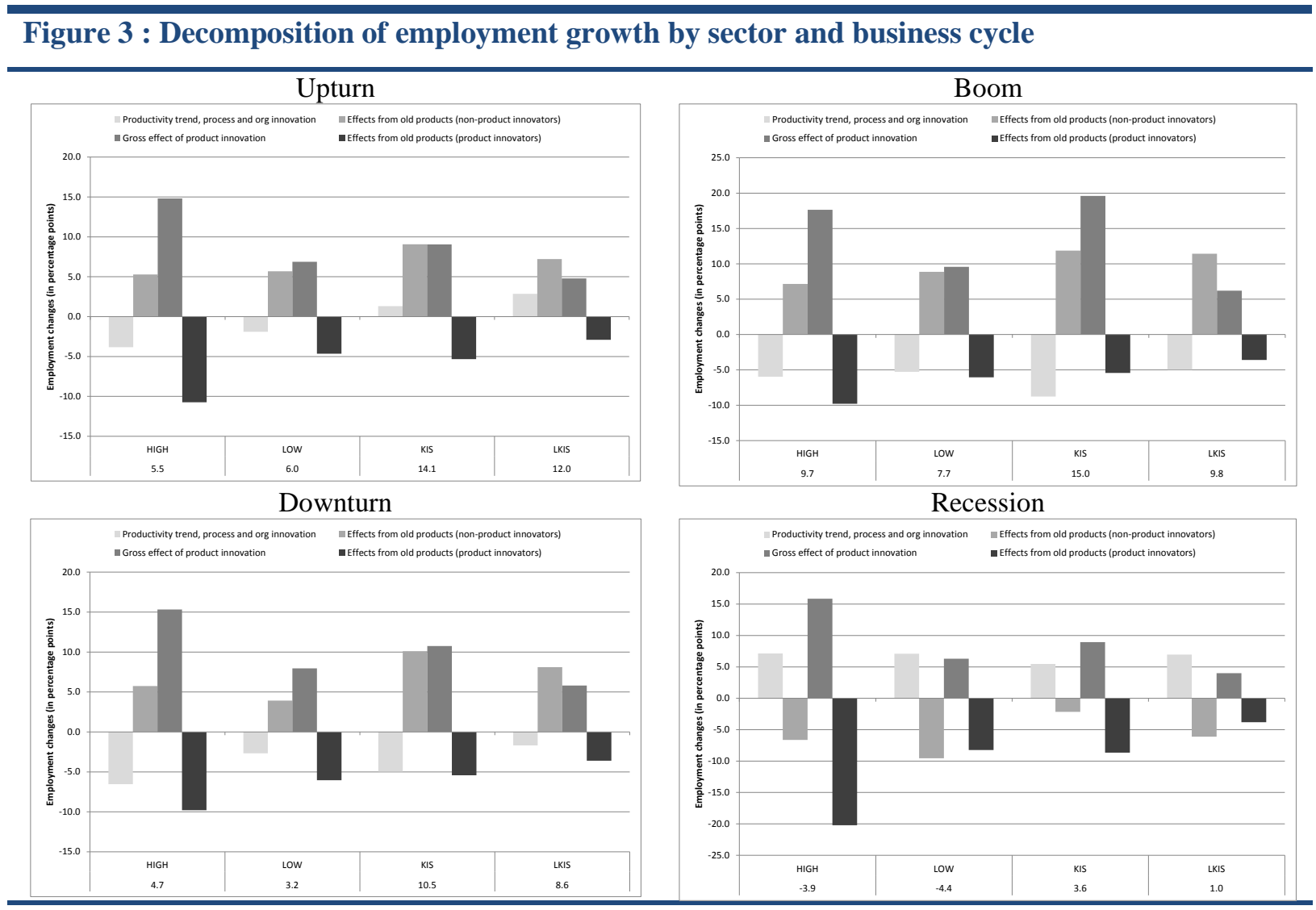

Notes: Decomposition of the weighted average two-year employment growth rate across all firms in a given sector and business cycle phase.

An interesting question is how innovative firms in these four sectors perform during a recession. Can the positive compensation effect of product innovation unfold despite stagnating or even decreasing incomes and poor prospects of future demand? Figure 3 reveals that the compensation effect of product innovation via sales of new products is remarkably stable in all four sectors during a recession. In high-tech manufacturing, for example, there is only a small difference in this value between the four stages of the business cycle. It is the displacement effect of product innovation which considerably amplifies in a recession, leading to employment losses in manufacturing and less growth in services. Negative externalities almost double in high-tech manufacturing and in knowledge-intensive services compared to the upturn or downturn stage. This increase is one major reason why employment goes down during a recession across all sectors. The second major reason for employment losses during a recession is the contribution of old products to employment growth, which turns negative in all four sectors. 


\begin{tabular}{|c|c|c|c|c|}
\hline & HIGH & LOW & KIS & LKIS \\
\hline \multicolumn{5}{|l|}{ Whole Period } \\
\hline Employment growth & 3.8 & 3.0 & 10.1 & 7.5 \\
\hline General productivity trend in production of old products (1) & -1.6 & 0.3 & 0.4 & 2.2 \\
\hline Displacement effect of process innovations (2) & -0.1 & -0.1 & 0.0 & -0.1 \\
\hline Displacement effect of organisational innovation (3) & -0.6 & -0.6 & -0.4 & -0.1 \\
\hline Output growth due to old products (non-product innovator) (4) & 2.9 & 2.0 & 6.2 & 4.2 \\
\hline Net contribution of product innovation (5) & 3.2 & 1.4 & 3.9 & 1.3 \\
\hline Demand reduction in old products (displacement effect) (5a) & -12.5 & -6.0 & -6.6 & -3.3 \\
\hline Demand increase in new products (gross effect) (5b) & 15.7 & 7.4 & 10.5 & 4.6 \\
\hline \multicolumn{5}{|l|}{ Upturn } \\
\hline Employment growth & 5.5 & 6.0 & 14.1 & 12.0 \\
\hline General productivity trend in production of old products (1) & -2.7 & -1.1 & 2.3 & 3.5 \\
\hline Displacement effect of process innovations (2) & -0.3 & -0.2 & -0.2 & 0.1 \\
\hline Displacement effect of organisational innovation (3) & -0.9 & -0.6 & -0.8 & -0.7 \\
\hline Output growth due to old products (non-product innovator) (4) & 5.3 & 5.7 & 9.1 & 7.2 \\
\hline Net contribution of product innovation (5) & 4.1 & 2.2 & 3.7 & 1.9 \\
\hline Demand reduction in old products (displacement effect) (5a) & -10.7 & -4.6 & -5.3 & -2.9 \\
\hline Demand increase in new products (gross effect) (5b) & 14.8 & 6.9 & 9.1 & 4.8 \\
\hline \multicolumn{5}{|l|}{ Boom } \\
\hline Employment growth & 9.7 & 7.7 & 15.0 & 9.8 \\
\hline General productivity trend in production of old products (1) & -5.9 & -5.6 & -7.0 & -5.6 \\
\hline Displacement effect of process innovations (2) & 0.1 & -0.1 & 0.7 & -0.4 \\
\hline Displacement effect of organisational innovation (3) & -0.2 & 0.4 & -2.5 & 1.0 \\
\hline Output growth due to old products (non-product innovator) (4) & 7.2 & 8.9 & 11.9 & 11.4 \\
\hline Net contribution of product innovation (5) & 8.5 & 4.1 & 11.9 & 3.3 \\
\hline Demand reduction in old products (displacement effect) (5a) & -9.1 & -5.5 & -7.7 & -2.9 \\
\hline Demand increase in new products (gross effect) (5b) & 17.6 & 9.6 & 19.6 & 6.2 \\
\hline \multicolumn{5}{|l|}{ Downturn } \\
\hline Employment growth & 4.7 & 3.2 & 10.5 & 8.6 \\
\hline General productivity trend in production of old products (1) & -6.2 & -2.0 & -4.4 & -1.5 \\
\hline Displacement effect of process innovations (2) & -0.1 & -0.2 & 0.0 & 0.2 \\
\hline Displacement effect of organisational innovation (3) & -0.2 & -0.4 & -0.6 & -0.4 \\
\hline Output growth due to old products (non-product innovator) (4) & 5.7 & 3.9 & 10.1 & 8.1 \\
\hline Net contribution of product innovation (5) & 5.5 & 1.9 & 5.3 & 2.2 \\
\hline Demand reduction in old products (displacement effect) (5a) & -9.8 & -6.0 & -5.4 & -3.6 \\
\hline Demand increase in new products (gross effect) (5b) & 15.3 & 8.0 & 10.8 & 5.8 \\
\hline \multicolumn{5}{|l|}{ Recession } \\
\hline Employment growth & -3.9 & -4.4 & 3.6 & 1.0 \\
\hline General productivity trend in production of old products (1) & 6.9 & 7.4 & 4.6 & 7.2 \\
\hline Displacement effect of process innovations (2) & 0.0 & -0.1 & -0.2 & 0.1 \\
\hline Displacement effect of organisational innovation (3) & 0.2 & -0.2 & 1.0 & -0.4 \\
\hline Output growth due to old products (non-product innovator) (4) & -6.6 & -9.5 & -2.2 & -6.1 \\
\hline Net contribution of product innovation (5) & -4.4 & -1.9 & 0.3 & 0.2 \\
\hline Demand reduction in old products (displacement effect) (5a) & -20.2 & -8.2 & -8.7 & -3.8 \\
\hline Demand increase in new products (gross effect) (5b) & 15.9 & 6.3 & 8.9 & 4.0 \\
\hline
\end{tabular}

Notes: Decomposition of the weighted average two-year employment growth rate across all firms in a given sector (and business cycle phase).

Altogether, the net effect of product innovation on employment (as the sum of the gross effect of product innovation and displacement effects from old products for innovators) is negative in the two manufacturing sectors during recessions; employment growth from product innovation is not able to 
offset demand decreases in old products in manufacturing. However, since this net employment effect for product innovators is smaller than the employment losses due to decreases in demand for old products of non-product innovators, we can say that product innovation nevertheless has a stabilizing effect on employment in the recession. Product innovators in service industries, in contrast, are even able to create enough new employment to offset decreasing sales in old products and all productivity and substitution effects in the recession, leading to a small employment gain. These smaller losses may also be explained by a higher import and export penetration in manufacturing than in services, and the resulting higher exposure of manufacturing firms to export markets (OECD 2010); international trade was hit much harder than domestic economic activity in the global financial crisis which implies that export-intensive manufacturing firms lost more turnover than service firms.

\section{Decomposition at Industry Level}

To evaluate heterogeneity in the relationship between employment creation and destruction in more detail and gain more insight into the drivers of employment growth we repeat the regression and the decomposition analysis at industry level (Table 9 and 10 in the Annex). Figure 4 compares employment gains from new products (dark bars) with losses from old products for product innovators (light bars) by industry. The figure includes a bar for each industry in upturn, boom, downturn and recession. Industries are sorted by increasing variance of gains and losses. For comparison, we also added the results at sectoral level on the right side of the Figure.

Hypothesis H1 stated that job creation but also job destruction from innovation increases with technology intensity. Figure 3 provides evidence that further supports this hypothesis. We find low-technology and less knowledge-intensive industries such as transport, wholesale, food or textile on the left side of the figure. This position indicates only low contributions of innovation to changes in employment, but also a low degree of creative destruction measured by employment losses in old products for innovators in these sectors. However, we should consider that overall employment growth in these industries is below average as well. High-tech industries and knowledge-intensive services such as telecommunications, electrical equipment and electronics, machinery or the chemical industry represent the other end of the distribution. Gains and losses from innovation are particularly strong in telecommunications. During economic boom periods, innovation drove employment growth in this sector by more than $30 \%$ in two years. However, telecommunications also exhibits the highest employment losses from innovation. Performing simple mean difference tests of compensation and displacement effects (across all four business cycles and industries), Table 6 shows that in high-tech industries both displacement and compensation effects are significantly higher than in low-tech industries. Similarly, both effects are higher in knowledge-intensive industries than in less knowledge-intensive industries. Furthermore, we find the net effect of product innovation to significantly increase with technology intensity. Altogether, the data support $\mathrm{H} 1$ that job creation and job destruction increases with technology intensity. 
Figure 4: Compensation and displacement effects of product innovation by industry and business cycle

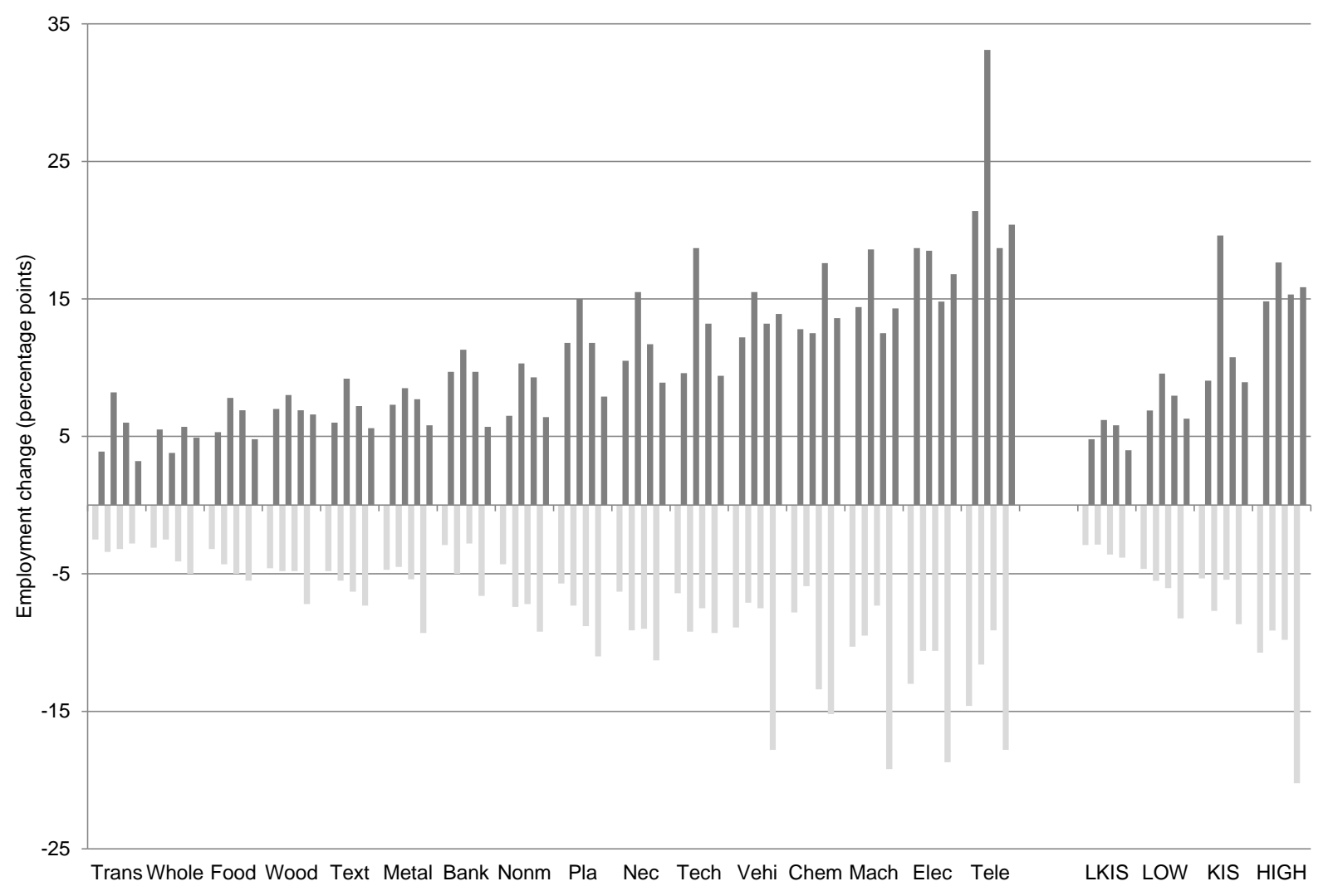

Notes: For each industry, the four dark bars show the positive compensation effect of product innovation (5b) in the four business cycle phases (upturn, boom, downturn, recession). The light bars present the displacement effects of product innovation (5a) for each business cycle phase. Both compensation and displacement effects refer to product innovators. All figures are weighted.

Hypothesis $\mathrm{H} 2$ stated that compensation and displacement effects are smaller in services than in manufacturing. Table 6 shows that displacement effects are indeed significantly smaller in service industries than in manufacturing (at the $10 \%$ level). However, we do not find compensation effects to be significantly different. The latter result is mainly driven by the telecommunication industry. Excluding this industry, we would find compensation effects to be significantly larger in manufacturing industries (p-value; 0.0136). Overall, the data only partly confirms H2.

Furthermore, in Figure 4 a clear pattern of how the displacement and the compensation effect evolve through various stages of the business cycle appears. In 13 of the 16 industries, job creation from innovation - the compensation effect - is highest in the boom period. In 10 of the 16 industries the compensation effect is smallest during recessions. This result clearly points to the importance of the demand effect for employment growth. Recessions, in contrast, are the period with the largest job destruction from the displacement effect in 15 of the 16 industries. Job losses are usually smallest during upturns. This pattern is also visible in all four sectors. 


\begin{tabular}{|c|c|c|c|c|}
\hline & Industries & Mean & t-stat & p-value \\
\hline \multirow[t]{2}{*}{ Displacement effects } & HIGH & -11.425 & -4.1955 & $0.0002 * * *$ \\
\hline & LOW & -6.564 & & \\
\hline \multirow[t]{2}{*}{ Compensation effects } & HIGH & 14.994 & 8.4168 & $0.0000 * * *$ \\
\hline & LOW & 8.436 & & \\
\hline \multirow[t]{2}{*}{ Net effect } & HIGH & 3.569 & 1.4072 & $0.0865^{*}$ \\
\hline & LOW & 1.871 & & \\
\hline \multirow[t]{2}{*}{ Displacement effects } & KIS & -8.5667 & -3.9544 & $0.0009 * * *$ \\
\hline & LKIS & -3.325 & & \\
\hline \multirow[t]{2}{*}{ Compensation effects } & KIS & 15.075 & 4.3509 & $0.0004^{* * *}$ \\
\hline & LKIS & 5.150 & & \\
\hline \multirow[t]{2}{*}{ Net effect } & KIS & 6.508 & 2.6736 & $0.0095^{*}$ \\
\hline & LKIS & 1.825 & & \\
\hline \multirow[t]{2}{*}{ Displacement effects } & Manufacturing & -8.332 & -1.6444 & $0.0547^{*}$ \\
\hline & Services & -6.470 & & \\
\hline \multirow[t]{2}{*}{ Compensation effects } & Manufacturing & 10.821 & -0.1550 & 0.5609 \\
\hline & Services & 11.105 & & \\
\hline \multirow[t]{2}{*}{ Net effect } & Manufacturing & 2.489 & -1.7173 & 0.9514 \\
\hline & Services & 4.635 & & \\
\hline \multicolumn{5}{|c|}{$\begin{array}{l}\text { Notes: The mean was calculated as mean over all displacement and compensation effects across all industries and business } \\
\text { cycles, respectively. HIGH industries comprise chemicals, machinery, electronics and vehicles, LOW all other manufacturing } \\
\text { industries. KIS industries consist of telecommunication, banking and technical services; LKIS includes wholesale and transport. } \\
\text { Reported are p-values of a one-sided mean difference tests with unequal variances. }\end{array}$} \\
\hline
\end{tabular}

The evidence presented above shows how absolute job creation and job destruction change over the business cycle and between sectors. However, we cannot read from this figure in which stages of the business cycle innovation matters most for employment growth. Thus, we have calculated in Figure 5 the net effect of product innovation (gains from new products minus losses from old products for innovators) as a fraction of total employment growth for upturn, downturn and boom periods. Recession periods are left out for an easier illustration. This indicator measures the share of employment growth which can be attributed to product innovation.

The figure reveals that the net effect of product innovation is most relevant in high-technology manufacturing industries where 80 to $120 \%$ of employment growth can be attributed to the net product innovation effect. In low-technology manufacturing and knowledge-intensive services, around half of the employment gains can be attributed to the net product innovation effect, while the other half is generated by higher sales from existing products. This is an indication that innovation is relevant for employment in all sectors of the economy - not just in high-tech manufacturing. However, the Figure also demonstrates that the net effect is larger in high-tech manufacturing than in KIS, and larger in low-tech manufacturing than in LKIS in all stages of the business cycle. We would consider a different ranking as a falsification of $\mathrm{H} 2$. 
Figure 5: Net product innovation as a fraction of total employment growth at sectoral and industry level

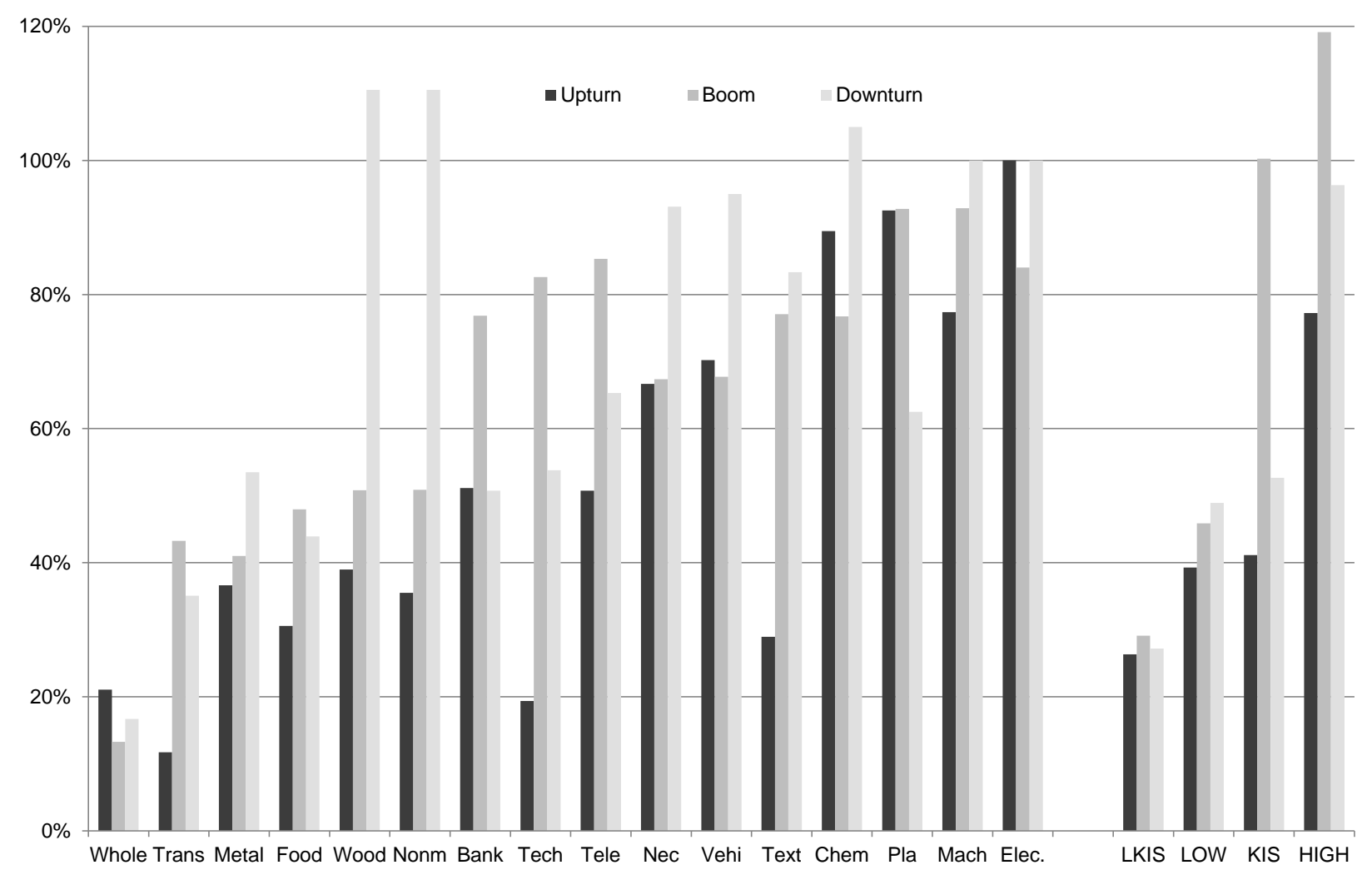

Notes: Based on decomposition analysis in Table 10 in the Appendix.

At the industry level, equipment and electronics, the chemical industry, or machinery stand out. In these industries, the net effect of innovation has almost the same size as total employment growth, which indicates that employment gains from higher sales of old products are completely absorbed by the employment-dampening effects process innovation, organisational innovation and general productivity increases. At the other end of the distribution, wholesale, transport, metal products or food products are typical sectors where innovation plays only a minor role for employment growth. Those industries gain only around half of their employment growth from innovation. This may hamper employment growth, which is lower than in high-tech industries. However, the aforementioned sectors also reveal a lower employment volatility in terms of employment losses from lower sales of old products.

In contrast to Figure 4, the timing of employment effects of innovation is less clear in Figure 5. The effect of innovation is strongest in boom periods (6 out of 16 industries) and the following downturn (8/16), and lowest in upturn periods. The high relevance of innovation in an economic downturn may be explained by lagged effects of the investments from the previous economic boom. In high-tech manufacturing and knowledge-intensive services product innovation is the main driver for employment growth in boom periods. In upturns and downturns, old products contribute the most to employment growth in these two industries. This finding is also confirmed by the data at industry level. 


\section{Conclusions}

This paper investigated employment creation and destruction from innovation. Results indicate that the employment-creating effect of new products and services promotes jobs growth in general. This positive effect, however, is not straightforward; employment gains are degraded by employment losses from innovation-related externalities, by employment losses from process and organisational innovation and by general productivity increases. Overall, there is a positive net contribution of innovation to employment growth.

"Creative destruction” and structural change in terms of employment gains and losses intensifies with rising technology intensity of sectors and industries (H1). There is also a clear hierarchy between service and manufacturing industries across all stages of the business sector with respect to compensation and displacement effects, despite a considerable heterogeneity in both effects within manufacturing and services. High-tech manufacturing shows the strongest compensation and displacement effects, followed by knowledge-intensive services, low-tech manufacturing and less knowledge-intensive services. As a result, the hypothesis (H2) that compensation and displacement effects are smaller in services than in manufacturing is only partly confirmed, and the results point to a finer differentiation than the simple duality of manufacturing and service sectors.

The analysis provides important insights for innovation and industrial policy. A first important finding relates to the sources of employment growth: regression analyses found only minor variations in the relationship between innovation output and employment growth across sectors and industries; one percent sales growth from new products transfers into roughly one percent of gross employment growth. Thus, the variation in employment growth across the sample is rather the result of sectoral and industry differences in the share of innovative firms or in additional sales from new products each firm creates.

This result highlights the importance of both, supply side and demand side technology policy designs (Steinmüller 2010); on the one hand, policy should aim at raising the share of innovative firms in the economy, and keep it stable in downturns and recessions. Non-innovators are not able to compensate losses in sales of their existing products with innovations. Broad horizontal funding schemes such as tax credits for R\&D and innovation are an instrument targeted to lower the threshold for non-innovative firms. However, as Hud and Hussinger (2015) show, public subsidies could not prevent firms from shifting funds from $R \& D$ to non-R\&D areas in a recession. ${ }^{12}$

On the other hand, policy can influence sales growth from new products and therefore influence the rate of diffusion of new technologies by demand-side measures. Examples are policies that spread information about new technologies; such policies aim at raising awareness about new technologies and may

\footnotetext{
${ }^{12}$ However, their study focuses on small and medium-sized enterprises (SMEs) only.
} 
influence adoption decisions of potential customers of innovative firms. This instrument, however, is only suited for selected technologies where the state has an interest in (Edler and Georghiou 2007), or which yield potentially high social benefits such as environmental technologies (Mowery, Nelson and Martin 2010). Hence, policy instruments at the demand side may be restricted to raising general awareness for innovation and increase the willingness to experiment.

A potentially fruitful area for innovation may also be environmental technologies. A couple of studies recently point out that environmental innovation can be a driver for jobs growth (Licht and Peters 2013), and may even provide more new employment than other types of innovation (Gagliardi, Marin and Miriello 2016). These results may also shed a different light on the relationship between innovation, jobs growth and (environmental) regulation (Vona et al. 2015) by pointing to employment gains from regulation.

The analysis also found a considerable heterogeneity in innovation-related employment gains and losses across sectors and industries. Should policy exploit this heterogeneity by focussing support measures on high-technology industries where the largest net employment gains from innovation appeared in the past? We do not see that the results support such a policy for two reasons. First, classifications such as hightechnology or low-technology hide a lot of intra-group heterogeneity (Clausen 2007; Srholec and Verspagen 2012). In addition, there are other factors than the sectoral classification that interact with employment growth such as firm size, location, country-specific regulation, etc. A focus on high-tech manufacturing or knowledge-intensive services would overlook technical learning and upgrading in lowtechnology firms which - despite the label - can be highly innovative and lead to employment growth as well (Som 2012). The analysis indeed demonstrated that also low-technology and less knowledgeintensive industries generate around half of their employment gains from innovation. Second, a focus on high-tech manufacturing or knowledge-intensive services has some trade-offs. The analysis also shows that larger employment gains are accompanied by larger losses from negative externalities such as business stealing at the industry level. A focus on high-tech would therefore also increase employment volatility and creative destruction. This may be a good thing from the perspective of industrial policy, because it means that employment is relocated from less productive to more productive activities, firms and sectors. However, from the employment policy perspective structural change incurs adjustment costs from temporal frictional unemployment. Against the background of our results, we see a more promising path to higher employment by increasing the share of innovators and making low-tech more high-tech than to solely focus on high-tech.

The global financial crisis has brought manufacturing industries back into fashion of economic policy (European Commission 2012, 2014). Countries with large manufacturing sectors seemed to be less affected by the crisis than countries with high shares of service industries. Demands for a "reindustrialisation" were made, setting a goal of 20\% manufacturing share on GDP for Europe by 2020 
(European Commission 2012). From the perspective of this paper, a link between service industries and poor labour market performance cannot be established. However, we have to point to some limitations of our analysis when we compare manufacturing and services. First, we do not account for spillovers between sectors. Input output-data provides evidence that manufacturing $R \& D$ incorporated in products is an important driver for productivity in other sectors (Hauknes and Knell 2009). However, this is also true for KIS. Second, the analysis does not account for firm entry and exit. Higher birth and death rates of firms in service sectors (OECD 2014) may bias average employment growth rates in service firms. In addition to these limitations, our analysis would have benefitted from more detailed employment information. CIS data only provide the number of employees in headcounts but no specific information on the actual hours worked or on more specific information on employment contracts like the duration. This clearly limits the analysis; in particular if sectors or industries differ in these dimension. 


\section{References}

Acemoglu, D. 2002. “Directed Technical Change.” The Review of Economic Studies 69(4): 781-809.

Aghion, P., and P. Howitt. 1992. “A Model of Growth Through Creative Destruction.” Econometrica 60(2): 323-351.

Bartelsman, E. J., and M. E. Doms. 2000. "Understanding Productivity: Lessons from Longitudinal Microdata.” Journal of Economic Literature 38(3): 569-594.

Baum, C.F., M.E. Schaffer, and S. Stillman. 2007. "Enhanced Routines for Instrumental Variables/GMM Estimation and Testing." STATA Journal 7: 465-506.

Baumol, W. J. 2012. The Cost Disease. Why Computers Get Cheaper and Health Care Doesn't. New Haven: Yale University Press.

Bloom, N., M. Schankerman, and J. Van Reenen. 2013. “Identifying Technology Spillovers and Product Market Rivalry.” Econometrica 81(4): 1347-1393.

Bogliacino, F., and M. Pianta. 2010. "Innovation and Employment: a Reinvestigation using Revised Pavitt classes.” Research Policy 39(6): 799-809.

Breschi, S., F. Malerba, and L. Orsenigo. 2000. “Technological Regimes and Schumpeterian Patterns of Innovation.” Economic Journal 110: 388-410.

Castellacci, F. 2007. “Technological Regimes and Sectoral Differences in Productivity Growth.” Industrial and Corporate Change 16(6): 1105-1145.

Caves, R. E. 1998. "Industrial Organization and New Findings on the Turnover and Mobility of Firms.” Journal of Economic Literature 36(4): 1947-1982.

Chandy, R. K., and G. J. Tellis. 1998. “Organizing for Radical Product Innovation: The Overlooked Role of Willingness to Cannibalize.” Journal of Marketing Research 35(4): 474-487.

Chennells, L., and J. Van Reenen. 2002. The Effects of Technical Change on Skills, Wages and Employment: A Survey of the Micro-econometric Evidence. In Productivity, Inequality, and the Digital Economy: A Transatlantic Perspective, edited by N. Greenan, Y. L'Horty, and J. Mairesse, 175-224. Cambridge [Mass.]: MIT Press.

Clausen, T. H. 2007. Firm Heterogeneity within Industries: How Important is "Industry" to Innovation? Oslo: Centre for Technology, Innovation and Culture, University of Oslo.

Clogg, C.C., E. Petkova, and A. Haritou. 1995. "Statistical Methods for Comparing Regression Coefficients between Models.” The American Journal of Sociology 100(5): 1261-1293.

Cohen, W. M. 2010. Fifty Years of Empirical Studies of Innovative Activity and Performance. In Handbook of the Economics of Innovation, edited by B. A. Hall, and N. Rosenberg, 129-213. Amsterdam: Elsevier.

Dachs, B., M. Hud, C. Köhler, and B. Peters. 2016. Employment Effects of Innovation over the Business Cycle: Evidence from European Countries. Mannheim: ZEW Discussion Paper No. 16-076. 
Dachs, B., and B. Peters. 2014. "Innovation, Employment Growth and Foreign Ownership of Firms. A European Perspective.” Research Policy 43(1): 214- 232.

Dosi, G., and R. Nelson. 2010. Technical Change and Industrial Dynamics as Evolutionary Processes. In Handbook of the Economics of Innovation, edited by B. A. Hall, and N. Rosenberg, 52-126. Amsterdam: Elsevier.

Edler, J., and L. Georghiou. 2007. "Public Procurement and Innovation—Resurrecting the Demand Side.” Research Policy 36(7): 949-963.

European Commission. 2012. A Stronger European Industry for Growth and Economic Recovery. Industrial Policy Communication Update. Brussels: Communication from the Commission to the Council, the European Parliament, the Economic and Social Committee and the Committee of the Regions -COM(2012) 582.

European Commission. 2014. For a European Industrial Renaissance. Brussels: Communication from the Commission to the European Parliament, the Council, The European Economic and Social Committee and the Committee of the Regions, COM (2014) 14/2.

EUROSTAT. 2016a. Eurostat Indicators on High-tech industry and Knowledge-intensive Services, $\begin{array}{llllllll}\text { Annex } & 2 & - & \text { High-tech } & \text { Aggregation }\end{array}$ http://ec.europa.eu/eurostat/cache/metadata/Annexes/htec_esms_an2.pdf. Accessed on July 26th, 2016

EUROSTAT. 2016b. Eurostat Indicators on High-tech Industry and Knowledge-intensive Services, $\begin{array}{lllllll}\text { Annex } & 3 & - & \text { High-tech } & \text { Aggregation }\end{array}$ http://ec.europa.eu/eurostat/cache/metadata/Annexes/htec esms an3.pdf. Accessed on July 27th, 2016.

Gagliardi, L., G. Marin, and C. Miriello. 2016. "The Greener the Better? Job Creation Effects of Environmentally-friendly Technological Change.” Industrial and Corporate Change.

Gallouj, F., and M. Savona. 2009. "Innovation in Services: A Review of the Debate and a Research Agenda.” Journal of Evolutionary Economics 19(2): 149-172.

Greenan, N., and D. Guellec. 2000. “Technological Innovation and Employment Reallocation.” Labour 14(4): 547-590.

Hall, B. H., F. Lotti, and J. Mairesse. 2008. "Employment, Innovation, and Productivity: Evidence from Italian Microdata.” Industrial and Corporate Change 17(4): 813-839.

Harrison, R., J. Jaumandreu, J. Mairesse, and B. Peters. 2008. Does Innovation Stimulate Employment? A Firm-Level Analysis Using Comparable Micro-Data From Four European Countries. Cambridge, MA: NBER Working Papers 14216, National Bureau of Economic Research.

Harrison, R., J. Jaumandreu, J. Mairesse, and B. Peters. 2014. “Does Innovation Stimulate Employment? A Firm-Level Analysis Using Comparable Micro-Data From Four European Countries.” International Journal of Industrial Organization, 36(C): 29-43.

Hauknes, J., and M. Knell. 2009. "Embodied Knowledge and Sectoral Linkages: An Input-Output Approach to the Interaction of High- and Low-tech Industries.” Research Policy 38(3): 459-469. 
Hauser, J., G. J. Tellis, and A. Griffin. 2006. "Research on Innovation: A Review and Agenda for Marketing Science.” Marketing Science 25(6): 687-717.

Heerde, H. J. v., S. Srinivasan, and M. G. Dekimpe. 2010. "Estimating Cannibalization Rates for Pioneering Innovations.” Marketing Science 29(6): 1024-1039.

Howells, J. 2002. “The Response of Old Technology Incumbents to Technological Competition - Does the Sailing Ship Effect Exist?” Journal of Management Studies 39(7): 887-906.

Hud, M., and K. Hussinger. 2015. "The Impact of R\&D Subsidies during the Crisis.” Research Policy 44(10): 1844-1855.

Kleibergen, F., and R. Paap. 2006, "Generalized Reduced Rank Tests Using the Singular Value Decomposition.” Journal of Econometrics 133, 97-126.

König, H., G. Licht, and H. Buscher. 1995. Employment, Investment and Innovation at the Firm Level. In OECD (ed.), The OECD Jobs Study - Investment, Productivity and Employment: 67-81. Paris.

Krüger, J. J. 2008. "Productivity and Structural Change: A Review of the Literature." Journal of Economic Surveys 22(2): 330-363.

Lachenmaier, S., and H. Rottmann. 2011. "Effects of Innovation on Employment: A Dynamic Panel Analysis.” International Journal of Industrial Organization 29(2): 210-220.

Licht, G., and B. Peters. 2013. Do Green Innovations Stimulate Employment - Firm-level Evidence From Germany. Mannheim: WWW for Europe Working Paper No. 53.

Lomax, W., K. Hammond, R. East, and M. Clemente. 1997. “The Measurement of Cannibalization.” Journal of Product \& Brand Management 6(1): 27-29.

Lucchese, M., and M. Pianta. 2012. "Innovation and Employment in Economic Cycles.” Comparative Economic Studies 54(June): 341-359.

Marsili, O. 2001. The Anatomy and Evolution of Industries: Technological Change and Industrial Dynamics. Cheltenham, UK and Northampton, MA, USA: Edward Elgar.

Mendonça, S. 2013. „The “Sailing Ship Effect”: Reassessing History as a Source of Insight on Technical Change.” Research Policy 42(10): 1724-1738.

Miles, I. 2005. Innovation in Services. In The Oxford Handbook of Innovation, edited by J. Fagerberg, D. C. Mowery, and R. R. Nelson, 433-458. Oxford: Oxford University Press.

Mowery, D. C., R. R. Nelson, and B. Martin. 2010. “Technology Policy and Global Warming: Why New Policy Models are Needed (or Why Putting New Wine in Old Bottles Won’t Work)” Research Policy 39(6): 1011-1023.

OECD and Eurostat. 2005. Oslo Manual. Guidelines for Collecting and Interpreting Innovation Data (3rd ed.). Paris: Organisation for Economic Co-operation and Development.

OECD. 2010. Measuring Globalisation: OECD Economic Globalisation Indicators 2010. Paris: Organisation for Economic Co-operation and Development.

OECD 2014. Entrepreneurship at a Glance 2014. Paris: Organisation for Economic Co-operation and Development. 
Schmookler, J. 1966. Invention and Economic Growth. Cambridge, MA: Harvard University Press.

Schumpeter, J. A. 1942. Capitalism, Socialism and Democracy. New York: Routledge.

Smolny, W. 2002. "Employment Adjustment at the Firm Level. A Theoretical Model and Empirical Investigation for West German Manufacturing.” Labour 16(1): 65-88.

Som, O. 2012. Innovation without R\&D: Heterogeneous Innovation Patterns of Non-R\&D-Performing Firms in the German Manufacturing Industry. Wiesbaden: Springer Gabler.

Srholec, M., and B. Verspagen. 2012. „The Voyage of the Beagle into Innovation: Explorations on Heterogeneity, Selection, and Sectors.” Industrial and Corporate Change 21(5): 1221-1253.

Steinmueller, W. E. 2010. Economics of Technology Policy. In Handbook of the Economics of Innovation, edited by B. A. Hall, and N. Rosenberg, 1182-1218. Amsterdam: Elsevier.

Stock, J.H. and M. Yogo. 2005. Testing for Weak Instruments in Linear IV Regression. In Identification and Inference for Econometric Models: Essays in Honor of Thomas J. Rothenberg, edited by J.H. Stock, and D.W.K. Andrews, 80-108. New York: Cambridge University Press.

Sutton, J. 1997. “Gibrat's Legacy.” Journal of Economic Literature 35(1): 40-59.

Tether, B. S. 2005. "Do Services Innovate (Differently)? Insights from the European Innobarometer Survey.” Industry and Innovation 12(2): 153-184.

Tether, B. S., C. Hipp, and I. Miles. 2001. "Standardisation and Particularisation in Services: Evidence from Germany.” Research Policy 30(7): 1115-1138.

Veugelers, R. 2013. Trends, Challenges and Prospects for Manufacturing in Europe. In R. Veugelers, ed, Manufacturing Europe's Future. Brussels: Breughel Blueprint Series Vol. XXI.

Vivarelli, M. 2014. "Innovation, Employment and Skills in Advanced and Developing Countries: A Survey of Economic Literature.” Journal of Economic Issues 48(1): 123-154.

Vona, F., G. Marin, D. Consoli, and D. Popp. 2015. Green Skills. Cambridge [Mass.]: NBER Working Paper No. 21116. 


\begin{tabular}{|c|c|c|c|c|c|}
\hline \multirow[t]{2}{*}{ Industry } & \multirow[t]{2}{*}{ Variable } & \multirow{2}{*}{$\begin{array}{l}\text { NACE } \\
\text { Rev. } 1.1\end{array}$} & \multirow{2}{*}{$\begin{array}{l}\text { NACE } \\
\text { Rev. } 2\end{array}$} & \multicolumn{2}{|c|}{ Observations } \\
\hline & & & & $\mathbf{N}$ & $\%$ \\
\hline \multicolumn{6}{|l|}{ Manufacturing } \\
\hline Food / beverages / tobacco & FOOD & $15-16$ & $10-12$ & 29,144 & 14.28 \\
\hline Textile / wearing apparel / leather & TEXT & $17-19$ & $13-15$ & 29,019 & 14.22 \\
\hline Wood / paper / printing & WOOD & $\begin{array}{c}20-21 \\
22.2-22.3\end{array}$ & $16-18$ & 23,252 & 11.39 \\
\hline Chemicals & CHEM & 24 & $20-21$ & 10,879 & 5.33 \\
\hline Rubber / plastics & PLAS & 25 & 22 & 11,145 & 5.46 \\
\hline Non-metallic mineral products & NONM & 26 & 23 & 11,584 & 5.68 \\
\hline Basic and fabricated metals & BASM & $27-28$ & $24-25$ & 28,447 & 13.94 \\
\hline Machinery & MACH & 29, 33.3 & 28,33 & 20,844 & 10.21 \\
\hline Electrical engineering & ELEC & $\begin{array}{c}\text { 30-32, } \\
33.2,33.4-33.5\end{array}$ & $26-27$ & 15,124 & 7.41 \\
\hline Vehicles & VEHI & 34-35 & $29-30$ & 9,648 & 4.73 \\
\hline $\mathrm{Nec}$ & NEC & $36,33.1$ & $31-32$ & 15,027 & 7.36 \\
\hline Total & & & & 204,113 & 100 \\
\hline \multicolumn{6}{|l|}{ Services } \\
\hline Wholesale & WHOLE & 51 & 46 & 54,298 & 34.42 \\
\hline Transport/storage/post & TRANS & $\begin{array}{c}60-63 \\
64.1\end{array}$ & 49-53, 79 & 33,420 & 21.19 \\
\hline $\begin{array}{l}\text { Telecomm. / computer program. / } \\
\text { information services }\end{array}$ & TELE & $\begin{array}{c}\text { 64.3, } \\
72.1-72.4,72.6\end{array}$ & $61-63$ & 15,684 & 9.94 \\
\hline Banks / insurances & BANK & $65-67$ & $64-66$ & 12,588 & 7.98 \\
\hline Technical services & TECH & $74.2-74.3,73$ & $71-72$ & 15,974 & 10.13 \\
\hline Consultancies & $\mathrm{CON}$ & $74.1,74.4$ & 69-70, 73 & 8,104 & 5.14 \\
\hline Other business related services & OBRS & $74.5-74.8,70.3$ & $74,78,80-82$ & 11,096 & 7.03 \\
\hline Media & MEDIA & 22.1, 92.1-92.2 & $58-60$ & 6,588 & 4.18 \\
\hline Total & & & & 157,752 & 100 \\
\hline $\begin{array}{l}\text { Notes: Up to CIS2006 the indust } \\
\text { économiques dans les Communaut } \\
\text { Source: CIS3, CIS4, CIS2006, CIS }\end{array}$ & $\begin{array}{l}\text { was b } \\
\text { 2), since } \\
\text { 2010, Eur }\end{array}$ & $\begin{array}{l}\text { NACE Rev. } 1 \\
8 \text { NACE Rev. } 2 \\
\text { wn calculation }\end{array}$ & $\begin{array}{l}\text { E: Nomenc } \\
\text { en used as in }\end{array}$ & $\begin{array}{l}\text { Enérale } \\
\text { assifica }\end{array}$ & $\begin{array}{l}\text { tivités } \\
\text { stem. }\end{array}$ \\
\hline
\end{tabular}




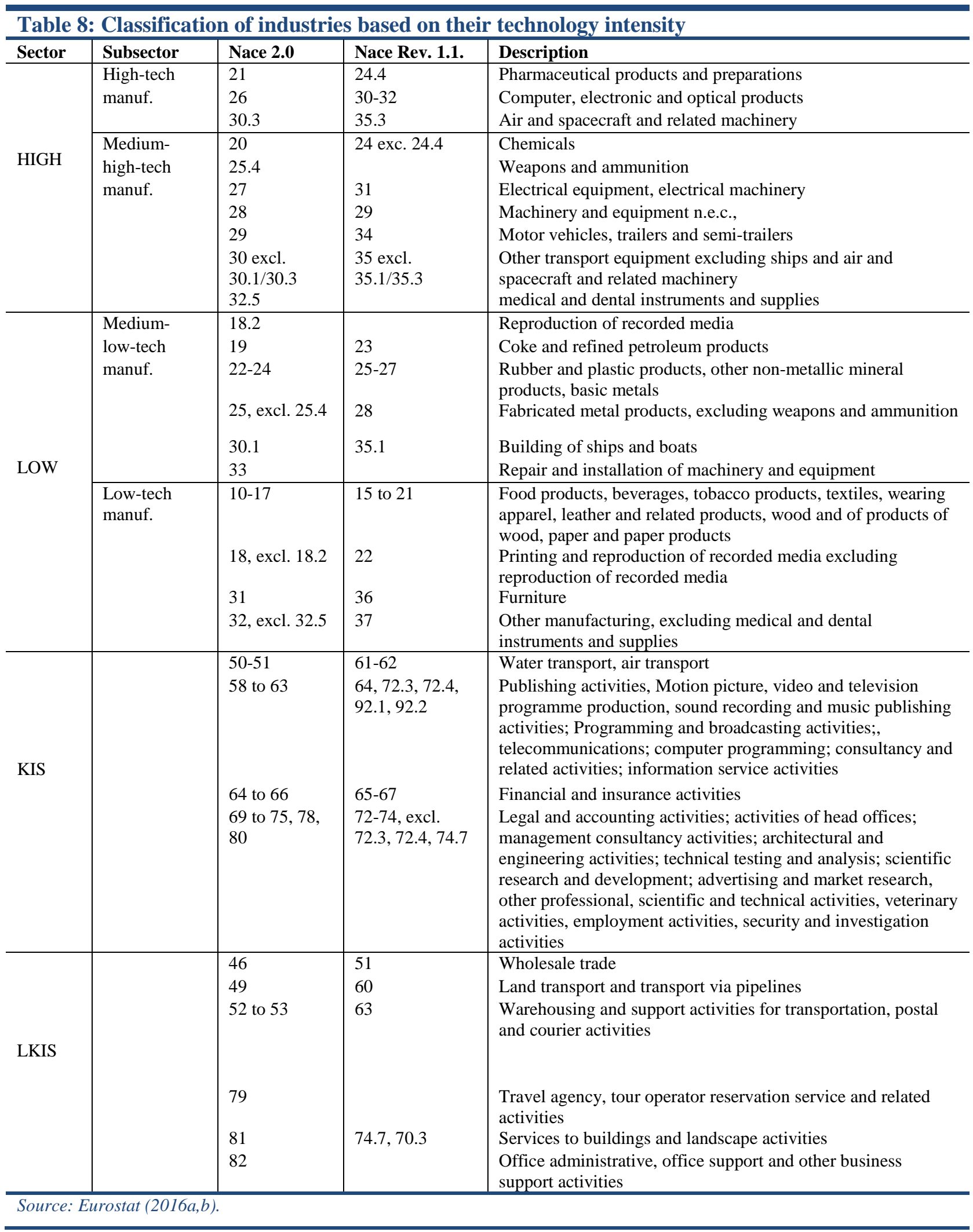




\begin{tabular}{|c|c|c|c|c|c|c|c|c|c|c|c|c|c|c|c|c|c|}
\hline & & Food & Text & Wood & Chem & Plas & Nonm & Metal & Mach & Elec. & Vehi & Nec & Whole & Trans & Tele & Bank & Tech \\
\hline \multirow[t]{7}{*}{ Upturn } & SGR_NEWPD & $1.03^{* * *}$ & $0.97^{* * *}$ & $1.03^{* * *}$ & $1.09^{* * *}$ & $1.10^{* * *}$ & $0.81^{* * *}$ & $1.05^{* * *}$ & $1.02^{* * *}$ & $1.08^{* * *}$ & $0.92^{* * *}$ & $1.00^{* * *}$ & $1.11^{* * *}$ & $1.01^{* * *}$ & $0.91 * * *$ & $1.18^{* * *}$ & $0.91^{* * *}$ \\
\hline & PC & -1.03 & 2.61 & -3.09 & -2.27 & 0.31 & -2.06 & 0.65 & -1.88 & 1.05 & 1.36 & 1.37 & $3.85^{* *}$ & -1.95 & -4.83 & $5.68^{*}$ & $-10.80^{* * *}$ \\
\hline & ORGA & $-5.64 * * *$ & $-5.40 * * *$ & $-5.59 * * *$ & $-4.22^{* *}$ & $-3.83^{* *}$ & -1.907 & -1.99 & $-4.15^{* *}$ & -2.89 & $-4.74 * * *$ & $-5.78 * * *$ & $-6.04 * * *$ & 1.43 & 1.27 & -1.39 & -4.37 \\
\hline & $\beta=1$ & 0.66 & 0.62 & 0.66 & 0.30 & 0.13 & $0.00^{* * *}$ & 0.45 & 0.71 & 0.14 & 0.18 & 0.98 & 0.28 & 0.92 & 0.15 & 0.23 & 0.22 \\
\hline & $\mathrm{J}$ & 0.11 & 0.84 & 0.25 & 0.77 & 0.31 & 0.95 & 0.47 & 0.80 & 0.45 & 0.14 & 0.46 & 0.26 & 0.94 & 0.56 & 0.52 & 0.86 \\
\hline & KP Wald F & 144.1 & 115.2 & 155.1 & 148.0 & 91.9 & 56.4 & 96.3 & 118.6 & 152.1 & 85.3 & 95.8 & 89.4 & 47.9 & 101.8 & 10.9 & 183.0 \\
\hline & Obs & 9,125 & 11,706 & 7,591 & 3,574 & 3,347 & 3,908 & 8,501 & 5,833 & 5,604 & 3,635 & 4,690 & 15,257 & 10,632 & 4,452 & 4,085 & 4,952 \\
\hline \multirow[t]{7}{*}{ Boom } & SGR_NEWPD & $0.90^{* * *}$ & $1.16^{* * *}$ & $0.94^{* * *}$ & $0.94^{* * *}$ & $1.06^{* * *}$ & $1.00^{* * *}$ & $0.98^{* * *}$ & $0.96^{* * *}$ & $0.93^{* * *}$ & $1.07^{* * *}$ & $0.89 * * *$ & $0.49 * *$ & $1.23^{* * *}$ & $0.96^{* * *}$ & $0.68^{*}$ & $1.05^{* * *}$ \\
\hline & PC & 1.48 & 0.25 & -3.85 & -1.08 & $5.39 *$ & -0.15 & 0.33 & 5.22 & -2.96 & 4.13 & -1.93 & $-11.66^{* *}$ & 2.79 & 1.95 & -10.23 & $20.17 * *$ \\
\hline & ORGA & 0.65 & 3.06 & 1.10 & -2.75 & -2.47 & 4.59 & 1.49 & -1.05 & 2.71 & -0.36 & -2.75 & 4.10 & 2.09 & -2.38 & 0.18 & -4.93 \\
\hline & $\beta=1$ & 0.30 & 0.15 & 0.62 & 0.61 & 0.53 & 0.98 & 0.73 & 0.62 & 0.48 & 0.39 & 0.14 & $0.02^{* *}$ & 0.43 & 0.83 & 0.35 & 0.80 \\
\hline & $\mathrm{J}$ & 0.61 & 0.47 & 0.28 & 0.38 & 0.29 & 0.99 & 0.75 & 0.39 & 0.31 & 0.64 & 0.57 & 0.26 & 0.51 & 0.38 & 0.20 & 0.25 \\
\hline & KP Wald F & 51.1 & 57.0 & 33.33 & 66.2 & 44.64 & 18.1 & 50.4 & 57.0 & 97.7 & 94.0 & 43.5 & 23.6 & 8.12 & 10.4 & 2.5 & 16.3 \\
\hline & Obs & 1,988 & 1,940 & 1,761 & 1,045 & 915 & 892 & 2,180 & 1,434 & 1,645 & 942 & 1,119 & 2,404 & 1,630 & 906 & 1,023 & 1,387 \\
\hline \multirow{7}{*}{$\begin{array}{l}\text { Down } \\
\text { turn }\end{array}$} & SGR_NEWPD & $0.91^{* * *}$ & $1.12^{* * *}$ & $1.05^{* * *}$ & $1.12^{* * *}$ & $0.88^{* * *}$ & $1.11^{* * *}$ & $1.01^{* * *}$ & $1.07^{* * *}$ & $0.86^{* * *}$ & $1.00^{* * * *}$ & $1.02^{* * *}$ & $0.97 * * *$ & $1.22^{* * *}$ & $0.96^{* * *}$ & $1.06^{* * *}$ & $1.02^{* * *}$ \\
\hline & PC & $-3.49 *$ & 0.09 & -0.76 & -0.87 & -3.83 & 3.45 & -2.16 & 2.50 & $-6.44 *$ & -4.81 & $-5.22^{* *}$ & 0.04 & 2.90 & -2.78 & 3.72 & 0.99 \\
\hline & ORGA & -1.23 & -0.93 & $-4.38 * * *$ & -2.41 & -2.92 & -3.90 & -0.90 & -0.70 & 0.65 & 1.26 & -2.48 & 0.38 & -2.99 & 3.14 & $-6.33^{* *}$ & -3.07 \\
\hline & $\beta=1$ & $0.08^{*}$ & $0.09 *$ & 0.42 & 0.31 & $0.10^{*}$ & 0.32 & 0.84 & 0.18 & $0.08^{*}$ & 0.99 & 0.74 & 0.44 & 0.33 & 0.48 & 0.68 & 0.77 \\
\hline & $\mathrm{J}$ & 0.92 & 0.69 & 0.61 & 0.57 & 0.28 & 0.10 & 0.30 & 0.10 & 0.92 & 0.33 & 0.78 & 0.59 & 0.15 & 0.79 & 0.16 & 0.20 \\
\hline & KP Wald F & 194.3 & 177.2 & 184.9 & 73.4 & 59.6 & 86.5 & 211.3 & 147.4 & 83.1 & 57.1 & 116.1 & 345.8 & 14.0 & 291.5 & 39.5 & 172.4 \\
\hline & Obs & 10,094 & 9,946 & 7,690 & 3,346 & 3,743 & 3,877 & 9,358 & 7,094 & 4,221 & 2,751 & 5,080 & 20,200 & 11,188 & 5,000 & 4,022 & 4,639 \\
\hline \multirow{7}{*}{$\begin{array}{l}\text { Reces } \\
\text { sion }\end{array}$} & SGR_NEWPD & $0.95^{* * *}$ & $0.88^{* * *}$ & $1.04^{* * *}$ & $0.82^{* * * *}$ & $0.87 * * *$ & $1.13^{* * *}$ & $0.89^{* * *}$ & $1.03^{* * *}$ & $1.08^{* * *}$ & $1.06^{* * * *}$ & $0.95^{* * *}$ & $1.07^{* * *}$ & $0.98^{* * *}$ & $1.05^{* * *}$ & $1.13^{* * *}$ & $1.03^{* * *}$ \\
\hline & PC & -1.91 & -0.78 & 0.06 & $-4.35 *$ & $-7.03^{* *}$ & -0.21 & 1.20 & 2.57 & -0.20 & 4.78 & -2.77 & 0.68 & -0.07 & 0.36 & 3.95 & -3.22 \\
\hline & ORGA & -1.52 & -0.63 & 0.37 & -0.14 & 1.80 & -1.95 & -1.47 & 1.55 & -0.51 & -5.06 & 0.51 & -0.65 & -1.97 & 3.05 & -0.07 & 2.08 \\
\hline & $\beta=1$ & 0.40 & $0.09 *$ & 0.45 & $0.06^{*}$ & 0.12 & 0.26 & 0.11 & 0.63 & 0.36 & 0.78 & 0.37 & 0.57 & 0.86 & 0.46 & 0.58 & 0.75 \\
\hline & $\mathrm{J}$ & 0.53 & 0.72 & 0.20 & 0.77 & 0.15 & 0.61 & 0.93 & 0.27 & 0.76 & 0.62 & 0.62 & 0.16 & 0.59 & 0.25 & 0.49 & 0.68 \\
\hline & KP Wald F & 92.5 & 102.4 & 147.3 & 17.7 & 32.0 & 31.9 & 74.8 & 43.9 & 62.5 & 26.2 & 134.1 & 41.1 & 13.1 & 60.3 & 43.4 & 69.9 \\
\hline & Obs & 7,667 & 5,344 & 5,783 & 2,740 & 3,021 & 2,817 & 7,966 & 6,181 & 3,503 & 2,224 & 3,947 & 15,482 & 9,260 & 5,170 & 3,285 & 4,789 \\
\hline
\end{tabular}


Table 10: Decomposition of employment growth over the business cycle by industry

\begin{tabular}{|c|c|c|c|c|c|c|c|c|c|c|c|c|c|c|c|c|c|}
\hline & & Food & Text & Wood & Chem & Pla & Nonm & Metal & Mach & Elec. & Vehi & Nec & Whole & Trans & Tele & Bank & Tech \\
\hline \multirow[t]{8}{*}{ Upturn } & Employment growth & 7.2 & 3.8 & 5.9 & 5.7 & 6.7 & 6.2 & 7.1 & 5.3 & 5.8 & 4.7 & 6.3 & 11.4 & 12.8 & 13.4 & 13.3 & 16.0 \\
\hline & General productivity trend (1) & 0.6 & 1.1 & -0.9 & -0.6 & -6.4 & -3.2 & -1.2 & -2.7 & -4.2 & -2.3 & -2.0 & 3.4 & 4.0 & 1.4 & -5.5 & 7.1 \\
\hline & Displacement effect of process innovations (2) & -0.1 & 0.2 & -0.5 & -0.2 & 0.0 & -0.3 & 0.1 & -0.2 & 0.1 & 0.1 & 0.2 & 0.5 & -0.2 & -0.3 & 0.7 & -1.1 \\
\hline & Displacement effect of organisational innovation (3) & -1.7 & -1.2 & -1.6 & -1.8 & -1.5 & -0.6 & -0.7 & -1.7 & -1.2 & -1.9 & -1.8 & -2.1 & 0.4 & 0.6 & -0.7 & -2.0 \\
\hline & Output growth of old products (for non-pd) (4) & 6.3 & 2.6 & 6.5 & 3.3 & 8.4 & 8.2 & 6.3 & 5.7 & 5.3 & 5.5 & 5.7 & 7.2 & 7.1 & 4.9 & 12.1 & 8.8 \\
\hline & Net contribution of product innovation (5) & 2.2 & 1.1 & 2.3 & 5.1 & 6.2 & 2.2 & 2.6 & 4.1 & 5.8 & 3.3 & 4.2 & 2.4 & 1.5 & 6.8 & 6.8 & 3.1 \\
\hline & Demand reduction in old products (5a) & -3.2 & -4.8 & -4.6 & -7.8 & -5.7 & -4.3 & -4.7 & -10.3 & -13.0 & -8.9 & -6.3 & -3.1 & -2.5 & -14.6 & -2.9 & -6.4 \\
\hline & Demand increase in new products (5b) & 5.3 & 6.0 & 7.0 & 12.8 & 11.8 & 6.5 & 7.3 & 14.4 & 18.7 & 12.2 & 10.5 & 5.5 & 3.9 & 21.4 & 9.7 & 9.6 \\
\hline \multirow[t]{8}{*}{ Boom } & Employment growth & 7.3 & 4.8 & 6.3 & 8.6 & 8.3 & 5.7 & 10.0 & 9.8 & 9.4 & 12.4 & 9.5 & 9.8 & 11.1 & 25.2 & 8.2 & 11.5 \\
\hline & General productivity trend (1) & -1.4 & -5.0 & -5.8 & -1.6 & -8.6 & -9.6 & -6.6 & -6.2 & -6.3 & -8.9 & -5.6 & -0.9 & -11.2 & -5.7 & -5.0 & -7.4 \\
\hline & Displacement effect of process innovations (2) & 0.2 & 0.0 & -0.7 & -0.1 & 0.5 & 0.0 & 0.0 & 0.4 & -0.2 & 0.4 & -0.2 & -1.0 & 0.3 & 0.1 & -1.0 & 2.0 \\
\hline & Displacement effect of organisational innovation (3) & 0.3 & 0.9 & 0.4 & -1.4 & -1.2 & 1.7 & 0.7 & -0.6 & 1.3 & -0.2 & -1.0 & 1.7 & 0.9 & -1.4 & 0.1 & -2.8 \\
\hline & Output growth of old products (for non-pd) (4) & 4.9 & 5.2 & 9.2 & 5.1 & 9.8 & 10.7 & 11.8 & 7.1 & 6.7 & 12.6 & 9.8 & 8.7 & 16.4 & 10.6 & 7.8 & 10.3 \\
\hline & Net contribution of product innovation (5) & 3.5 & 3.7 & 3.2 & 6.6 & 7.7 & 2.9 & 4.1 & 9.1 & 7.9 & 8.4 & 6.4 & 1.3 & 4.8 & 21.5 & 6.3 & 9.5 \\
\hline & Demand reduction in old products (5a) & -4.3 & -5.5 & -4.8 & -5.9 & -7.3 & -7.4 & -4.5 & -9.5 & -10.6 & -7.1 & -9.1 & -2.5 & -3.4 & -11.6 & -5.0 & -9.2 \\
\hline & Demand increase in new products (5b) & 7.8 & 9.2 & 8.0 & 12.5 & 15.0 & 10.3 & 8.5 & 18.6 & 18.5 & 15.5 & 15.5 & 3.8 & 8.2 & 33.1 & 11.3 & 18.7 \\
\hline \multirow{8}{*}{$\begin{array}{l}\text { Down } \\
\text { turn }\end{array}$} & Employment growth & 4.1 & 1.2 & 1.9 & 4.0 & 4.8 & 1.9 & 4.3 & 5.3 & 4.2 & 6.0 & 2.9 & 9.0 & 7.7 & 14.7 & 13.6 & 10.6 \\
\hline & General productivity trend (1) & -0.9 & -0.3 & -3.5 & -1.4 & -1.5 & 1.0 & -3.9 & -7.2 & -5.5 & -8.2 & -2.4 & 0.6 & -4.1 & -10.2 & 0.5 & -5.3 \\
\hline & Displacement effect of process innovations (2) & -0.4 & 0.0 & -0.1 & -0.1 & -0.4 & 0.5 & -0.3 & 0.2 & -0.5 & -0.5 & -0.5 & 0.0 & 0.3 & -0.2 & 0.4 & 0.1 \\
\hline & Displacement effect of organisational innovation (3) & -0.3 & -0.2 & -1.1 & -1.1 & -1.0 & -1.0 & -0.3 & -0.2 & 0.2 & 0.5 & -0.7 & 0.1 & -0.8 & 1.4 & -2.7 & -1.1 \\
\hline & Output growth of old products (for non-pd) (4) & 3.9 & 0.7 & 4.6 & 2.4 & 4.6 & -0.7 & 6.4 & 7.2 & 5.7 & 8.4 & 3.8 & 6.8 & 9.4 & 14.1 & 8.5 & 11.3 \\
\hline & Net contribution of product innovation (5) & 1.8 & 1.0 & 2.1 & 4.2 & 3.0 & 2.1 & 2.3 & 5.3 & 4.2 & 5.7 & 2.7 & 1.5 & 2.7 & 9.6 & 6.9 & 5.7 \\
\hline & Demand reduction in old products (5a) & -5.0 & -6.3 & -4.8 & -13.4 & -8.8 & -7.2 & -5.4 & -7.3 & -10.6 & -7.5 & -9.0 & -4.1 & -3.2 & -9.1 & -2.8 & -7.5 \\
\hline & Demand increase in new products (5b) & 6.9 & 7.2 & 6.9 & 17.6 & 11.8 & 9.3 & 7.7 & 12.5 & 14.8 & 13.2 & 11.7 & 5.7 & 6.0 & 18.7 & 9.7 & 13.2 \\
\hline \multirow{8}{*}{$\begin{array}{l}\text { Reces } \\
\text { sion }\end{array}$} & Employment growth & 0.0 & -5.4 & -5.2 & -0.4 & -3.7 & -7.9 & -6.5 & -3.6 & -4.4 & -7.2 & -4.7 & 0.1 & 1.7 & 7.1 & 3.4 & 3.4 \\
\hline & General productivity trend (1) & 4.8 & 4.0 & 5.0 & 4.2 & 5.5 & 11.7 & 11.7 & 9.4 & 3.0 & 7.9 & 7.1 & 8.6 & 6.2 & 3.6 & 7.4 & 6.9 \\
\hline & Displacement effect of process innovations (2) & -0.2 & -0.1 & 0.0 & -0.4 & -0.9 & 0.0 & 0.2 & 0.2 & 0.0 & 0.5 & -0.2 & 0.1 & 0.0 & 0.0 & 0.5 & -0.3 \\
\hline & Displacement effect of organisational innovation (3) & -0.4 & -0.1 & 0.1 & -0.1 & 0.6 & -0.5 & -0.5 & 0.6 & -0.2 & -1.8 & 0.1 & -0.2 & -0.5 & 1.5 & 0.0 & 0.9 \\
\hline & Output growth of old products (for non-pd) (4) & -3.5 & -7.6 & -9.7 & -2.5 & -5.9 & -16.4 & -14.4 & -8.8 & -5.3 & -9.9 & -9.3 & -8.2 & -4.4 & -0.5 & -3.5 & -4.1 \\
\hline & Net contribution of product innovation (5) & -0.7 & -1.6 & -0.6 & -1.6 & -3.0 & -2.7 & -3.5 & -4.9 & -1.9 & -3.8 & -2.4 & -0.1 & 0.4 & 2.5 & -0.9 & 0.2 \\
\hline & Demand reduction in old products (5a) & -5.5 & -7.3 & -7.2 & -15.2 & -11.0 & -9.2 & -9.3 & -19.2 & -18.7 & -17.8 & -11.3 & -5.0 & -2.8 & -17.8 & -6.6 & -9.3 \\
\hline & Demand increase in new products (5b) & 4.8 & 5.6 & 6.6 & 13.6 & 7.9 & 6.4 & 5.8 & 14.3 & 16.8 & 13.9 & 8.9 & 4.9 & 3.2 & 20.4 & 5.7 & 9.4 \\
\hline
\end{tabular}

